\title{
Ideias para uma termodinâmica noética e uma noética ígnea
}

\section{Ideas for a noetic thermodynamics and an igneous noetics}

\section{Marco Antonio Valentim*}

Resumo: 0 ensaio desenvolve o problema cosmológico da relação entre metafísica e termodinâmica, pensamento e ambiente, espírito e calor, com foco nos conceitos filosóficocientíficos de sistema (Serres, Bateson) e entropia (Prigogine \& Stengers, Georgescu-Roegen), em vista da catástrofe ambiental em curso. Seu objetivo principal é fundamentar a hipotese mágico-filosófica, baseada em Ficino e Agrippa, Starhawk e Castaneda, segundo a qual uma termodinâmica noética, ou uma noética ignea, é não só possível mas necessária para fazer sentido do Antropoceno como "Piroceno" (Pyne). Por sua origem antrópica, a catástrofe planetária atesta que o pensamento é intrinsecamente ígneo.

Palavras-chave: Sistema; Entropia; Antropia; Fogo; Catástrofe.

Abstract: The essay develops the cosmological problem of the relationship between metaphysics and thermodynamics, thought and environment, spirit and heat, focusing on the philosophical-scientific concepts of system (Serres, Bateson) and entropy (Prigogine \& Stengers, Georgescu-Roegen), in view of the ongoing environmental catastrophe. Its main objective is to substantiate the magical-philosophical hypothesis, based on Ficino and Agrippa, Starhawk and Castaneda, according to which a noetic thermodynamics, or an igneous noetics, is not only possible but necessary to make sense of the Anthropocene as "Pyrocene" (Pyne). By its anthropic origin, the planetary catastrophe attests that thought is intrinsically

Keywords: System; Entropy; Anthropy; Fire; Catastrophe.

$\bar{A}$ eksios Ōño, īlōn mīsās!

George R.R. Martin, A Song of Ice and Fire

\section{Demônios e sistemas}

The human security system is a projection of the intensity of the conflict between the xeno-agent (demon) and the system that registers new indefinable plagues mapped at the outer limits of the demon and the system.

Reza Negarestani, Cyclonopedia

A fim de explicar por hipótese "estados improváveis" na difusão do calor que emergem como "ilhas de ordem em um oceano de entropia"1, Maxwell postulou, em 1867, a existência hiperfísica de uma inteligência material capaz, por meio de agência consciente a respeito do que sucede entre diferentes sistemas físicos em contato, de adiar o inevitável equilíbrio termodinâmico, sua morte térmica. Produzindo, com acribia quase sobrenatural, assimetrias energéticas entre os sistemas, tal inteligência os sustentaria contra a tendência supostamente natural ao colapso. Em 1874, foi batizada por Kelvin de "demônio de Maxwell", "para enfatizar que a criatura, aquecendo o gás em um recipiente enquanto resfria o gás no outro, comete o pecado de violar a segunda lei da termodinâmica"2. Paradoxalmente, não fosse graças à incessante reiteração desse "pecado" - a violação de uma lei natural -, o universo físico estaria

${ }^{1}$ ALMEIDA, Simetria e entropia: sobre a noção de estrutura em Lévi-Strauss, 180.

2 ZOLNERKEVIC, Quantum Trickster, 48.

*Professor associado ao Departamento de Filosofia da Universidade Federal do Paraná, Curitiba, PR. E-mail: mavalentim@gmail.com ORCID: https://orcid.org/0000-0001-7950-1673 
desde há muito morto, tendo alcançado um estado final de equilíbrio energético pleno. "Mera fantasia"3?! De forma a demonstrar a efetividade concreta dessas entidades paradoxais, Almeida diz:

\begin{abstract}
Maxwell representou a violação da segunda lei da termodinâmica antropomorficamente como um demônio postado na porta de comunicação entre dois compartimentos. 0 demônio fecha ou abre a porta, dependendo do que vê. 0 demônio de Maxwell é guiado por informação, que utiliza para preservar estados improváveis. Assim, pode fechar a porta na maioria das vezes em que um objeto procura escapar do compartimento A para B, e abrir a porta na maioria dos casos em que um objeto procura voltar de B para A. [...] Preservando assim um estado discreto e improvável, o demônio impede o aumento da entropia. Demônios de Maxwell são máquinas de suprimir o tempo na única forma pela qual sua direção é reconhecível: o aumento da desordem, ou entropia. Podemos imaginar os demônios de Maxwell como uma variedade de mecanismos - seja repressão, consciência coletiva, tradição, votação, constituições. Regras, tabus, preferências, mapas, estilos e cosmologia são demônios de Maxwell. Uma máquina anti-entrópica restringe o universo dos mundos possíveis introduzindo restrições no movimento de vai-e-vem de objetos, como ocorre precisamente com a regras de casamento e os tabus, em sociedades de pequena escala, ou como regras alfandegárias, sistemas educacionais, em sociedades de grande escala. [...] Não são propriedades de objetos que os atribuem a uma ou a outra caixa, e sim, por assim dizer, critérios políticos: seja a decisão do grupo A, seja o conflito entre essa decisão e a decisão do grupo B. [...] 0 próprio demônio é parte do sistema que controla e está assim também sujeito à entropia. Com o tempo ele deixa de discriminar, como um porteiro bêbado por influência da clientela com a qual está em contínuo contato, e não mais é capaz de vetar a entrada de fregueses indesejáveis. Talvez por não serem capazes, impunemente, de obter informação, talvez por não serem capazes, sem custo, de se desfazerem da memória inútil acumulada em séculos, os demônios de Maxwell morrem enquanto demônios de Maxwell4.
\end{abstract}

O preço a pagar pela chance de evitar a morte térmica seria assim a plena assunção da materialidade do espírito: "0 próprio demônio é parte do sistema que controla e está assim também sujeito à entropia". De fato, como o espírito poderia agir sobre a matéria, lutar contra a degradação entrópica ou mesmo provocar o colapso dos sistemas físicos, sem estar concernido por ela, mais ainda, sem reconhecer sua própria situação e potência materiais? Por outro lado, se é verdade que "as transformações do espírito devem enraizar-se na matéria, subordinando-se assim a leis que regem máquinas reais" ${ }^{5}$, os demônios de Maxwell seriam como que máquinas espirituais, arranjos sencientes de matéria-energia, sem as quais as máquinas simplesmente "materiais" nunca poderiam funcionar, seja para alimentar a entropia, acelerando o tempo por sua pretensa supressão (no caso dos motores térmicos), ou para fazê-la arrefecer, retardando-o por seu controle provisório (no caso dos organismos vivos). Ao cerrar e descerrar comportas para controlar fluxos de matéria-energia, os demônios mantêm os sistemas abertos, perfazendo a diferença entre eles mediante a reiteração do seu desequilíbrio, sempre sob o perigo inexorável da morte térmica, fechamento absoluto, dos sistemas de que fazem parte. Logo, não se trata exatamente de "máquinas de anular o tempo" 6 , como seriam idealmente as máquinas mecânicas, mas sim de máquinas que, sem poder jamais suspender a irreversibilidade temporal, seriam, não obstante, dotadas da

3 ZOLNERKEVIC, Quantum Trickster, 49.

${ }^{4}$ ALMEIDA, Simetria e entropia: sobre a noção de estrutura em Lévi-Strauss, 184-185.

5 ALMEIDA, Simetria e entropia: sobre a noção de estrutura em Lévi-Strauss, 178.

${ }^{6}$ ALMEIDA, Simetria e entropia: sobre a noção de estrutura em Lévi-Strauss, 179. 
capacidade de orientar a flecha entrópica do tempo, em sentidos tão irreversíveis quanto imprevisíveis.

Outra termodinâmica? A pergunta se justifica diante do caráter aberrante da agência demoníaca para a termodinâmica clássica, caracterizada por um paradigma no qual o fechamento é tido como propriedade essencial e fundamental dos sistemas por satisfazer certo ideal de inteligibilidade que rejeita o imprevisível como "subjetivo", objetivamente nulo7. Para Serres, predominaria nessa concepção paradigmática e ideal uma conexão epistemologicamente necessária, não obstante metafisicamente problemática, entre o "axioma de fechamento para o universo do discurso" e o "isolamento térmico" do universo físico:

\begin{abstract}
Estamos na presença de três tipos de sistemas: o primeiro, lógico-matemático, é independente do tempo; o segundo, mecânico, está ligado ao tempo reversível; o terceiro, termodinâmico, está ligado ao tempo irreversível. No entanto, os três tipos têm em comum o fechamento. Eles constituem uma partição de um determinado universo, seja pelo chamado axioma de fechamento para o universo do discurso ou pela independência de movimentos e estabilidades em relação a todas as influências externas (assim como o mundo solar de Laplace em relação ao universo estelar) por isolamento térmico. Um sistema físico, no terceiro sentido, é isolado-fechado. Deve-se compreender por isso que nenhum fluxo de matéria, nenhuma circulação de calor, luz ou energia, atravessa as paredes que o definem e demarcam no espaço. Sob esta condição e somente sob esta condição, as duas leis da termodinâmica se aplicam e são válidas. Com a mais tênue abertura, o sistema não é mais governado por equações gerais ${ }^{8}$.
\end{abstract}

Assim, a segunda lei da termodinâmica, a da irreversibilidade entrópica, teria caráter meramente "estatístico", com "validade limitada apenas aos sistemas macroscópicos"9 escopo que abstrai propositalmente das "influências externas", lógicas e cósmicas, para garantir a consistência de "equações gerais". Tal abstração implica um duplo fechamento, o do isolamento térmico e do absoluto racional, exemplificáveis respectivamente pela motor térmico de Carnot como "máquina ideal"10 e pela razão pura de Kant como "sistema fechado"11.

Contudo, e se as comportas de ambos os sistemas fossem, ou já sempre estivessem, abertas? Será que a tendência inexorável ao colapso por meio do equilíbrio total - no limite, a chamada "morte térmica do universo" - não faria sentido como necessidade física absoluta somente por força do desejo metafísico do isolado? Da pressuposição mesma segundo a qual equilíbrio e fechamento são condições de possibilidade (compreensibilidade) dos sistemas físicos resulta uma "confusão entre irreversibilidade e degradação"12, espécie de obsessão pelo caos absoluto como fonte de certeza apodítica, à qual se precisaria escapar em vista de um necessário aprofundamento do "diálogo com a natureza"13. Devido a essa obsessão demoníaca, não é senão o próprio sistema pensamento-natureza que corre risco de colapso irreversível.

Mas o que seria de um sistema físico para além do governo transcendental da matéria pelo pensamento? Para Prigogine \& Stengers, essencialmente abertos, sistemas dinâmicos são por isso mesmo "instáveis", "sensíveis" tanto ao seu funcionamento interno quanto ao seu ambiente externo, "bifurcáveis" em direções imprevisíveis, em suma, caracterizados por uma

\footnotetext{
${ }^{7}$ Cf. PRIGOGINE \& STENGERS, Entre o tempo e a eternidade, 43-44.

8 SERRES, Hermes: Literature, Science, Philosophy, p. 72.

${ }^{9}$ CHAUÍ-BERLINCK \& MARTINS, As duas primeiras leis: uma introdução à termodinâmica, 160-161.

10 OLIVEIRA \& DECHOUM, Facilitando a compreensão da segunda lei da termodinâmica, 359-360.

${ }^{11}$ Cf. LEBRUN, Kant e o fim da metafísica, 41-43.

12 PRIGOGINE \& STENGERS, Entre o tempo e a eternidade, 171.

13 PRIGOGINE \& STENGERS, Entre o tempo e a eternidade, 124.
} 
evolução irreversível entre ordem e desordem, sempre "longe do equilíbrio"14. Ao invés de condições de possibilidade para todo sistema físico, equilíbrio e fechamento se revelam como situações-limite, que só se impõem como absolutamente necessárias por força do ideal, dominante na dinâmica clássica, que postula, com a subordinação da diacronia das forças à sincronia das formas, um abismo metafísico entre matéria e sentido. Fora desse ideal, irreversibilidade significa "quebra da simetria temporal"15: novidade e criatividade, intrínsecas à matéria. 0 reconhecimento da abertura dos sistemas termodinâmicos implica, portanto, um outro significado, bastante complexo, para a entropia enquanto grandeza termodinâmica, segundo o qual ela é intrinsecamente positiva e negativa, não necessariamente uma ou outra ${ }^{16}$. Se produz caos a partir de ordem, a entropia também "cria" ordem a partir de caos:

É necessário libertar-nos da ideia de que a atividade produtora de entropia é sinônimo de degradação, de nivelamento das diferenças. Pois, se é verdade que temos de pagar um preço entrópico para manter em seu estado estacionário o processo de termodifusão, também é verdade que esse estado corresponde a uma criação de ordem. Torna-se então possível um novo olhar: ver a "desordem" produzida pela manutenção do estado estacionário como o que nos permite criar uma ordem, uma diferença de composição química entre dois recintos. A ordem e a desordem mostram-se aqui não como opostas entre si, e sim como indissociáveis) ${ }^{17}$.

A consideração da mesma complexidade entrópica inspira a Serres o discernimento de um quarto tipo de sistema, para além daqueles três primeiros: sistema sujeito à segunda lei porém capaz de violá-la ao subverter o sentido da flecha do tempo através da manutenção do desequilíbrio em meio ao tempo irreversível - sistema "homeorrético", demoníaco:

O que podemos dizer atualmente sobre esse sistema? Primeiro, que é um sistema termodinâmico e informacional. De fato, ele recebe, armazena, troca e emite tanto energia quanto informação - em todas as formas, desde a luz do sol ao fluxo de matéria que passa através dele (alimento, oxigênio, calor, sinais). Esse sistema não está em equilíbrio, uma vez que a estabilidade termodinâmica propicia a morte, pura e simplesmente. Ele se encontra em um estado temporário de desequilíbrio e tende, tanto quanto possível, a manter esse desequilíbrio. Está, portanto, sujeito ao tempo irreversível da segunda lei, pois está morrendo. Mas luta contra esse tempo. [...] De fato, devido à torrente de energia e informação que atravessa o sistema sem interrupção, torna-se impossível concebê-lo como um sistema fechado-isolado. É um sistema aberto. [...] Em e pelo desequilíbrio, ele é relativamente estável. Mas aqui a invariância é única: nem estática nem homeostática, é homeorrética. É um rio que flui e permanece estável no contínuo colapso de suas margens e na erosão irreversível das montanhas ao seu redor. [...] 0 sistema vivo é homeorrético. [...] Este rio, quase estável embora irreversível, equilibrado sobre seu próprio desequilíbrio em estado precário de quase-equilíbrio no seu fluxo para a morte, transporta energia e informação, conhecimento de entropia e neguentropia, de ordem e desordem. [...] Em sentido completamente novo, o organismo sincroniza significados e direções, o contínuo e o descontínuo, o local e o global; combina memória, invariância,

\footnotetext{
${ }^{14}$ Cf. PRIGOGINE \& STENGERS, Entre o tempo e a eternidade, 62-69.

15 PRIGOGINE \& STENGERS, Entre o tempo e a eternidade, 5.

16 Cf. SCHRÖDINGER, 0 que é vida?, 80-86.

17 PRIGOGINE \& STENGERS, Entre o tempo e a eternidade, 54.
} 
plano, mensagem, perda, redundância, e assim por diante. É velho, mortal, e o transmissor de um novo ciclo. 0 organismo é um conversor temporal ${ }^{18}$.

Significa isso que a vida, em sua especificidade orgânica, faz exceção a uma dinâmica material de base, caracterizada por grau zero de complexidade? Tudo indica que, na exposição de Serres, o rio seja mais que uma metáfora, perfazendo um exemplo de sistema homeorrético diante do qual os demais tipos de sistemas seriam como que variantes menos complexas. Levada ao limite, é ao que conduz a ideia de que "a identidade de um sistema físico-químico é relativa à sua atividade"19. Trata-se justamente da sensibilidade senciente de todo sistema físico:

\begin{abstract}
A noção de sensibilidade implica que a definição das relações de um sistema com seu ambiente seja relativa ao regime de atividade desse sistema. A que é sensível um ser? Pelo que pode ele ser afetado? De que suas relações com seu mundo o tornam capaz? Tais questões já adquirem sentido para "seres" tão simples quanto os sistemas físico-químicos. Mas como elas não se colocariam com urgência ainda maior aos seres vivos, dotados de memória, capazes de aprender e de interpretar? Como não encontrariam elas um sentido mais crucial ainda quando se trata dos homens que a linguagem real torna sensíveis à indefinida multiplicidade de seus passados, dos futuros que elas podem temer ou esperar, das leituras divergentes e dispersas do presente? Não são as próprias ciências um dos vetores dessa sensibilidade?20.
\end{abstract}

Em vez de simplesmente "antropomorfizar" a física, as indagações de Prigogine \& Stengers apontam, bem como a descrição da homeorhésis orgânica por Serres, aprofundando postulação demonológica de Maxwell, para a indiscernibilidade entre sentido e matéria na evolução dos sistemas físicos em geral, a ponto de justificar a pretensão de uma termodinâmica noética, voltada à consideração do nexo originário entre espírito e calor, em particular, entre antropia e entropia ${ }^{21}$ - nexo, por sua vez, atestado contemporaneamente pela experiência catastrófica de que "a mansão das liberdades modernas repousa sobre uma base de uso de combustíveis fósseis em permanente expansão" 22.

\title{
Ecomental
}

Eu não percebo que exista algo que não seja natureza. Tudo é natureza. O cosmos é natureza. Tudo em que eu consigo pensar é natureza. Ailton Krenak, Ideias para adiar o fim do mundo

Se Prigogine \& Stengers explicitam as bases físicas, "inorgânicas", de um tal sistema "orgânico", quais seriam, por outro lado, seus fundamentos metafísicos? Bateson procura apresentá-los precisamente em vista da catástrofe socioambiental em curso. Em uma comunicação intitulada "Patologias da epistemologia", dirigida a terapeutas em um colóquio sobre saúde mental na Ásia e no Pacífico ocorrido no Havaí em 1969, ele formula um conceito "ecomental" de sistema:

De repente, nos últimos vinte anos, as noções de estrutura em circuito e diferença se uniram para nos dar uma concepção ampla do mundo em que vivemos - uma nova maneira de pensar sobre o que é uma mente. Deixem-me

\footnotetext{
18 SERRES, Hermes: Literature, Science, Philosophy, 74-76.

19 PRIGOGINE \& STENGERS, Entre o tempo e a eternidade, 69.

20 PRIGOGINE \& STENGERS, Entre o tempo e a eternidade, 69.

${ }^{21} \mathrm{Cf}$. VALENTIM, Extramundanidade e sobrenatureza: ensaios de ontologia infundamental, 262-291.

${ }^{22}$ CHAKRABARTY, 0 clima da história: quatro teses, 11.
} 
listar o que me parecem ser as características essenciais mínimas de um sistema, que aceitarei como características da mente:

(1) 0 sistema deve operar com e sobre diferenças.

(2) O sistema deve consistir em ciclos fechados ou redes de caminhos ao longo das quais diferenças e transformações de diferenças devem ser transmitidas. ( 0 que é transmitido através de um neurônio não é um impulso, e sim a notícia de uma diferença.)

(3) Muitos eventos dentro do sistema devem ser energizados pela parte do respondente e não por impacto da parte desencadeadora.

(4) 0 sistema deve mostrar autocorretividade na direção da homeostase e/ou na direção da fuga. Autocorretividade implica tentativa e erro ${ }^{23}$.

0 referido conceito de sistema como estrutura em circuito baseia-se no conceito mais elementar de diferença. Uma diferença consiste na informação pensada em função de sua transmissão, capaz de "fazer diferença" 24 , trazer novidade (instaurar uma assimetria irreversível, como diriam Prigogine \& Stengers). A diferença é, antes de mais nada, um fator de transformação. Basear o conceito de sistema no de diferença significa, portanto, compreender sistema como um complexo trans(in)formacional cuja dinâmica "autocorretiva" pode conduzir ao equilíbrio ambiental interno "e/ou" à fuga ao ambiente exterior. Todo sistema é aberto, para fora ou para dentro, diferencial; por isso, todo sistema comporta ou mesmo consiste em uma mente:

Essas características mínimas da mente são geradas sempre e onde quer que exista a estrutura em circuito de ciclos causais apropriada. A mente é uma função necessária e inevitável da complexidade apropriada, onde quer que essa complexidade ocorra. Mas essa complexidade ocorre em muitos outros lugares além do interior da minha cabeça e das suas. Chegaremos adiante à questão de saber se um homem ou um computador têm uma mente. Por ora, deixem-me dizer que uma floresta de sequóias ou um recife de coral com seu agregado de organismos entrelaçados em seus relacionamentos têm a estrutura geral necessária. A energia para as respostas de todo organismo é fornecida por seu metabolismo, e o sistema total age de maneira autocorretiva de várias maneiras. Uma sociedade humana comporta-se assim, com ciclos fechados de causação. Toda organização humana mostra tanto a característica autocorretiva quanto a potencialidade para fuga. Agora, vamos considerar por um momento a questão de saber se um computador pensa. Eu diria que isso não acontece. 0 que "pensa" e se engaja em "tentativa e erro" é homem mais computador mais ambiente. $\mathrm{E}$ as linhas entre homem, computador e ambiente são linhas puramente artificiais, fictícias. Elas são linhas através dos caminhos ao longo dos quais a informação, ou diferença, é transmitida. Elas não são limites do sistema de pensamento. 0 que pensa é o sistema total que se envolve em tentativa e erro, que é homem mais ambiente. Mas, se vocês aceitam a autocorretividade como critério de pensamento ou processo mental, então obviamente há "pensamento" acontecendo dentro do homem em nível autonômico para manter diversas variáveis internas. Da mesma forma, o computador, se ele controla sua temperatura interna, está produzindo algum pensamento simples dentro de $\mathrm{si}^{25}$.

\footnotetext{
${ }^{23}$ BATESON, Steps to an Ecology of Mind, 490.

24 BATESON, Steps to an Ecology of Mind, 489.

25 BATESON, Steps to an Ecology of Mind, 490-491.
} 
Trata-se nada menos que de animismo cibernético. 0 sistema - não o homem, nem o computador, nem o ambiente, tomados isoladamente - é que pensa. Pensamento acontece "sistematicamente" por meio da congregação entre agentes ("homem mais computador mais ambiente"). Desse ponto de vista, a distinção extensiva entre "dentro" e "fora" torna-se obsoleta: toda mente abre-se em exterioridade e interioridade. A rigor, a interioridade (mens in se conversa) seria apenas um aspecto do sistema mental essencialmente aberto (mens in alieno conversa). Segundo o exemplo de Bateson, o pensamento propriamente dito, como atividade de um sistema ecomental, consiste na relação trans(in)formacional entre homem, computador e ambiente. Mais além, sistema é uma estrutura ao mesmo tempo física, vital e espiritual, de modo que o próprio limite entre intra-humanidade e extra-humanidade se revela "puramente artificial, fictício": as linhas que as separam são linhas de transmissão, que juntam os elementos constituindo uma estrutura em circuito, rigorosamente mental. São caminhos, e não fronteiras.

Na sequência imediata de sua exposição, Bateson procura explicar seu conceito de sistema por meio da correção de uma "falácia epistemológica" tipicamente ocidental:

Com isso, começamos a perceber algumas das falácias epistemológicas da civilização ocidental. De acordo com o clima geral de pensamento na Inglaterra de meados do século XIX, Darwin propôs uma teoria da evolução e da seleção natural em que a unidade [unit] de sobrevivência era ou a linhagem familiar, ou a espécie ou subespécie, ou algo do tipo. Mas hoje é bastante óbvio que esta não é a unidade de sobrevivência no mundo biológico real. A unidade de sobrevivência é organismo mais ambiente. Estamos aprendendo, por amarga experiência, que o organismo que destrói seu ambiente se destrói a si mesmo. Se, então, corrigimos a unidade darwiniana de sobrevivência para incluir o ambiente e a interação entre organismo e ambiente, uma identidade muito estranha e surpreendente emerge: $a$ unidade de sobrevivência evolucionária acaba por ser idêntica à unidade da mente. Anteriormente pensávamos em uma hierarquia de taxa - indivíduo, linhagem familiar, subespécie, espécie etc. - como unidades de sobrevivência. Vemos agora uma hierarquia diferente de unidades - gene-em-organismo, organismo-em-ambiente, ecossistema etc. A ecologia, no sentido mais amplo, revela-se o estudo da interação e da sobrevivência de ideias e programas (isto é, diferenças, complexos de diferenças etc.) em circuitos ${ }^{26}$.

Pelo exemplo de falácia, é possível notar o efeito altamente subversivo do conceito ecomental de sistema: aplicado ao problema da evolução da vida, ele implica toda uma outra narrativa da especiação, na qual a "interação" entre diferenças, tanto de natureza quanto de escala, corresponde à "unidade de sobrevivência evolucionária". Trata-se de um certo tipo peculiar de unidade. Unit é algo como a unidade de um grupo, uma unidade grupal. À diferença da unidade sistemática da Ideia, que, em sentido kantiano, é absoluta, "solitária" porque total, trata-se de um coletivo, unidade intrinsecamente complexa e extrinsecamente parcial, capaz de (trans)formar um ambiente: estrutura em circuito feita de diferenças transmissíveis, e não totalidade sistemática composta de partes integráveis.

0 mais importante é que é precisamente essa característica ecomental do sistema pensemos no sistema abstrato homem-natureza -, que abre a possibilidade do colapso antievolucionário do ambiente cósmico, sob a forma extrema da "insanidade" ambiental (da natureza) como resposta trans(in)formacional catastrófica ao "erro epistemológico" (do homem):

Vamos agora considerar o que acontece quando vocês cometem o erro epistemológico de escolher a unidade errada: vocês terminam com a espécie

${ }^{26}$ BATESON, Steps to an Ecology of Mind, 491. 
versus a outra espécie ao redor dela ou versus o ambiente em que ela opera. Homem contra natureza. Você terminam, na verdade, com a Baía Kaneohe poluída, o Lago Erie uma barafunda verde viscosa, e "Vamos construir bombas atômicas maiores para matar os vizinhos do lado". Há uma ecologia de ideias ruins, assim como há uma ecologia de ervas daninhas, e é característico do sistema que o erro básico se propague. Ele se ramifica como um parasita enraizado nos tecidos da vida, e tudo entra em uma bagunça bastante peculiar. Quando vocês reduzem a sua epistemologia e agem com base na premissa "O que me interessa sou eu, ou minha organização, ou minha espécie", vocês eliminam a consideração de outros ciclos da estrutura de ciclos. Vocês decidem que querem se livrar dos dejetos da vida humana e que o Lago Erie será um bom lugar para colocá-los. Vocês se esquecem de que o sistema ecomental chamado Lago Erie é parte de seu [your] sistema ecológico mais amplo - e que, se o Lago Erie enlouquece, a insanidade dele é incorporada ao grande sistema de seu [your] pensamento e experiência ${ }^{27}$.

Se a premissa "O que me interessa sou eu" provoca o colapso mental do ambiente, seja sociopolítico e/ou cósmico, cabe conjecturar o que a premissa inversa - algo como a "lei do antropófago", "Só me interessa o que não é meu"28 - proporcionaria em termos de sanidade ecomental: exemplarmente, o fim do capitalismo enquanto "ecologia de ideias ruins", condição indispensável para a saúde do assim chamado "sistema Terra" ${ }^{29}$. Todo e qualquer ato de pensamento, por mais subjetivo que seja, conspira, em maior ou menor grau, para a insanidade ou a sanidade do ambiente cósmico. Se a antropia possui de imediato um efeito entrópico, definido-se parcialmente, senão mesmo fundamentalmente, por seu potencial termodinâmico (por exemplo, o de aquecer ou resfriar o ambiente), é porque espírito e matéria compõem um só sistema ecomental. Há uma mente imanente ao ambiente:

Quando separam a mente da estrutura a que ela é imanente, como um relacionamento humano, a sociedade humana, ou o ecossistema, vocês embarcam por causa disso, creio eu, em erro fundamental, que no fim certamente os ferirá. A luta pode ser boa para as suas almas enquanto vencer a batalha for fácil. Quando vocês têm uma tecnologia eficaz o suficiente para poder agir à altura de seus erros epistemológicos e criar estragos no mundo em que vivem, o erro é letal. 0 erro epistemológico é "tranquilo", está tudo bem, até o ponto em que vocês criam em torno de si um universo no qual esse erro se torna imanente a mudanças monstruosas do universo que vocês criaram e em que agora tentam viver. Vocês veem, nós não estamos falando da velha querida Mente Suprema de Aristóteles, São Tomás de Aquino e outros através das eras - a Mente Suprema que era incapaz de errar e incapaz de insanidade. Estamos falando de mente imanente, que é por demais capaz de insanidade, como todos vocês sabem por profissão. É exatamente por isso que vocês estão aqui. Esses circuitos e equilíbrios da natureza podem facilmente sair dos eixos, e eles inevitavelmente o fazem, quando certos erros básicos de nosso pensamento são reforçados por milhares de detalhes culturais ${ }^{30}$.

"Mente Suprema" dos filósofos, Deus seria, junto com o homem, seu arauto, o agente por excelência da destruição, e não da criação, do cosmos enquanto sistema universo-vida. Se o colapso desse sistema é possível, constituindo, no limite, um perigo iminente, é porque o ambiente cósmico é estruturalmente mental. Sob essa perspectiva, a entropia, em sua ambiguidade criadora e destruidora, consiste, antes de mais nada, na medida da saúde

\footnotetext{
27 BATESON, Steps to an Ecology of Mind, 491-492.

${ }^{28}$ ANDRADE, $A$ utopia antropofágica, 67.

${ }^{29}$ Cf. VEIGA, O Antropoceno e a ciência do sistema Terra.

30 BATESON, Steps to an Ecology of Mind, 493.
} 
ecomental do cosmos. A termodinâmica é indiscernivelmente física e noética. Donde o prognóstico sombrio sobre a "crise ecológica":

É evidente agora a muitas pessoas que há muitos perigos catastróficos que cresceram a partir dos erros ocidentais de epistemologia. [...] Talvez tenhamos até a chance de passar os próximos vinte anos sem nenhum desastre mais sério que a mera destruição de uma nação ou de um grupo de nações. Acredito que esse agregado massivo de ameaças ao homem e seus sistemas ecológicos surgiram de erros em nossos hábitos de pensamento em níveis profundos e parcialmente inconscientes. [...] [Mas] há poços de sanidade que ainda sobrevivem no mundo ${ }^{31}$.

Tudo pode acontecer, inclusive o anti-acontecimento. 0 cosmos, assim como a vida, pode sim morrer. Pior: isso pode suceder por obra de "nossos hábitos de pensamento em níveis profundos e parcialmente inconscientes", em última instância, por força de nossos desejos. A mente imanente ao ambiente é mortal, e nós, seus potenciais assassinos suicidários: "Estamos aprendendo, por amarga experiência, que o organismo que destrói seu ambiente se destrói a si mesmo".

\section{Anti-horário}

This is not a dream... not a dream. You are seeing what is actually occurring for the purpose of causality violation.

-John Carpenter, Prince of Darkness

Em “As raízes da crise ecológica”, Bateson aprofunda seu prognóstico para indicar quais "erros" e "falácias" da epistemologia ocidental, juntamente com "milhares de detalhes culturais", provocam o colapso mental do ambiente bem como o colapso ambiental da civilização. $O$ referido texto consiste em uma comunicação apresentada, em 1970, em nome do Comitê de Ecologia e Humanidade da Universidade do Havaí a representantes do poder público local, com vistas à aprovação de um projeto de lei ambiental de caráter protetivo. Trata-se da ecologia diante do Estado.

O documento é formado por treze proposições. Consideremos a terceira delas:

(3) Que todas as muitas ameaças em curso à sobrevivência do homem se resumem a três causas principais: progresso tecnológico; aumento populacional; certos erros no pensamento da cultura ocidental. Nossos "valores" estão errados. Acreditamos que esses três fatores fundamentais são condições necessárias para a destruição do nosso mundo. Em outras palavras, acreditamos otimisticamente que a correção de qualquer um deles nos salvaria ${ }^{32}$.

Progresso tecnológico e aumento populacional: trata-se de características essenciais de um mundo quente, que produz ao mesmo tempo "muita ordem por sua cultura" e "muita entropia por sua sociedade"33. Segundo Bateson, tais características, mais certa epistemologia, são fatores de destruição ambiental. Por outro lado, para que a destruição fosse interrompida, bastaria tão-somente a "correção" de um, "qualquer um", desses fatores: a cultura, a sociedade ou a filosofia. Desse ponto de vista, não há hierarquia entre eles, pois se condicionam mutuamente. Mas parece haver, sim, a prevalência de um quarto "fator" sobre cada um dos

\footnotetext{
${ }^{31}$ BATESON, Steps to an Ecology of Mind, 495.

32 BATESON, Steps to an Ecology of Mind, 498.

${ }^{33}$ Cf. LÉVI-STRAUSS, A antropologia diante dos problemas do mundo moderno, 57-62.
} 
outros em separado: o destino do mundo depende de como cultura, sociedade e filosofia se articulam entre si com respeito ao ambiente. Como esses quatro fatores se relacionam?

(4) Que esses fatores fundamentais certamente interagem. 0 aumento da população estimula o progresso tecnológico e cria aquela ansiedade que nos coloca contra o nosso ambiente como um inimigo; enquanto a tecnologia facilita o aumento da população e reforça nossa arrogância, ou hybris, frente ao ambiente natural. 0 diagrama em anexo ilustra as interconexões. Notar-seá que neste diagrama cada nicho se move no sentido dos ponteiros do relógio, denotando que cada um é por si só um fenômeno autopromotor (ou, como dizem os cientistas, "autocatalítico"): quanto maior a população, mais rapidamente ela cresce; quanto mais tecnologia tivermos, mais rápida será a taxa de novas invenções; e quanto mais acreditamos em nosso "poder" sobre um ambiente inimigo, mais "poder" parecemos ter e mais vingativo o ambiente parece ser. Da mesma forma, os pares de nichos são conectados no sentido horário para formar três subsistemas autopromotores ${ }^{34}$.

Representada por meio de um diagrama ${ }^{35}$, a "dinâmica da crise ecológica" é caracterizada por dois processos ligados: o reforço mútuo dos fatores em sua promoção isolada. Eles se catalisam uns aos outros a se auto-catalisarem. Parece simples, mas é um arranjo estranho: cultura, sociedade e filosofia interagem no sentido de provocar sua desarticulação mediante autocatálise. 0 sentido horário do movimento dos nichos no diagrama simboliza essa dinâmica paradoxal de mútua independência. Temos assim sociedade separada de cultura separada de filosofia, ou melhor, sociedade contra cultura contra filosofia, e vice-versa. E, nessa guerra de todos contra todos, o ambiente se torna o inimigo-mor.

Quais os efeitos dessa dinâmica autocatalítica colapsante? Conforme o diagrama, a resposta é inequívoca: uma cultura poluente, uma sociedade faminta e uma filosofia militar. Poluição, fome e guerra são as maneiras pelas quais o ambiente corrige catastroficamente o desequilíbrio dos nichos como subsistemas coindependentes:

(7) Sempre, em qualquer sistema vivo (isto é, ecológico), todo desequilíbrio crescente gerará seus próprios fatores limitantes como efeitos colaterais do crescente desequilíbrio. No nosso presente, começamos a conhecer algumas das maneiras que a Natureza tem de corrigir o desequilíbrio - fumaça, poluição, envenenamento por DDT, resíduos industriais, fome, chuva radioativa e guerra. Mas o desequilíbrio foi tão longe que não podemos confiar que a Natureza não vá sobrecorrigir [overcorrect] ${ }^{36}$.

Ao corrigir esse desequilíbrio, recusando sua pretensa conformidade a fins humanos, a "Natureza" não trabalha necessariamente a favor da manutenção do sistema ecomental "humano". Pelo contrário, esse sistema, enquanto regido pela dinâmica de autocatálise das partes, não é homeostático, mas antinatural. Sua "sobrecorreção" (overcorrection) significa colapso irreversível.

Como evitá-lo? Como fazer com que os subsistemas operem contra o colapso do sistema? Resposta: "O problema enfrentado pelo mundo e pelo Havaí é simplesmente como introduzir alguns processos anti-horários nesse sistema"37. Mas o que são processos antihorários? Será que, por contraste, poderíamos dizer que são aqueles em que os subsistemas interagem em mútua dependência, configurando uma espécie de alo-catálise? É como se, movendo-se em sentido horário, eles tendessem a fechar-se mutuamente, ao passo que, em

\footnotetext{
${ }^{34}$ BATESON, Steps to an Ecology of Mind, 498.

${ }^{35}$ Cf. BATESON, Steps to an Ecology of Mind, 499.

36 BATESON, Steps to an Ecology of Mind, 500.

37 BATESON, Steps to an Ecology of Mind, 498.
} 
sentido anti-horário, tendessem a abrir-se, também mutuamente: neste caso, teríamos sociedade mesclada a cultura mesclada a filosofia, ou ainda, filosofia para cultura para sociedade, e vice-versa. Entrelaçamento, e não fragmentação. Mas Bateson não vai tão longe. Ele diz apenas que bastaria introduzir "alguns" processos anti-horários. Ainda assim, disso se pode concluir, no mínimo, que o sentido anti-horário restitui imprevisibilidade à dinâmica do sistema ecomental, de modo a instaurar uma dinâmica alocatalítica de codependência, culminando com a abertura do sistema total ao ambiente cósmico, sob a forma da reconexão da mente humana com a "mente imanente ao ambiente".

Logo na sequência do seu comunicado, Bateson se concentra particularmente na análise do fator epistemológico, filosófico, da crise ecológica:

(8) Que as ideias que dominam nossa civilização atualmente datam, em sua forma mais virulenta, da Revolução Industrial. Elas podem ser resumidos assim:

(a) Somos nós contra o meio ambiente.

(b) Somos nós contra outros homens. É o indivíduo (ou a empresa individual ou a nação individual) que interessa. Podemos ter controle unilateral sobre o meio ambiente e devemos lutar por esse controle.

(c) Vivemos dentro de uma "fronteira" infinitamente em expansão.

(d) Determinismo econômico é senso comum.

(e) A tecnologia resolverá por nós.

Afirmamos que essas idéias são provadas simplesmente falsas pelas grandes, mas destrutivas, conquistas de nossa tecnologia nos últimos 150 anos. Da mesma forma, elas parecem ser falsas sob a perspectiva teoria ecológica moderna. A criatura que vence seu ambiente destrói-se a si mesma ${ }^{38}$.

É notável que a primeira característica das “ideias que dominam nossa civilização" seja sua origem histórica na revolução industrial. De fato, enquanto "ciência do fogo industrial" 39 , a termodinâmica transforma a metafísica da modernidade, inclinando-a na direção de um fascismo cósmico 40: "nós contra o ambiente", "nós contra outros homens", expansão ilimitada da fronteira civilizacional, "naturalização" da exploração da natureza pelo homem, bem como do homem pelo homem, e, por fim, fé messiânica na tecnologia como arma de solução final contra o ambiente extra-humano.

Para Bateson, essas ideias não são somente perigosas, mas também "falsas". Que critério de verdade guia seu juízo? Sem dúvida, um critério eminentemente pragmático: a verdade de um sistema - e todo sistema é uma mente ambientalmente situada - mede-se por seus efeitos ambientais, sejam internos ou externos ao sistema. 0 sistema noético em questão é absolutamente falso se opera contra o ambiente cósmico, a ponto de provocar sua própria destruição. A falsidade ecomental é autodestrutiva.

Não obstante, se diante da incomensurável diversidade geológica, biológica e etnológica do ambiente mais amplo, uma verdade ecomental é possível, a falsidade epistemológica do sistema ecomental instaurado com a revolução industrial revela sua contingência histórico-ontológica:

\footnotetext{
38 BATESON, Steps to an Ecology of Mind, 500-501.

39 PRIGOGINE \& STENGERS, A nova aliança: metamorfoses da ciência, 83.

${ }^{40}$ Cf. VALENTIM, Cosmologia e política no Antropoceno.
} 
(9) Que outras atitudes e premissas - outros sistemas de "valores" humanos governaram a relação do homem com seu ambiente e com seus semelhantes em outras civilizações e outras épocas. Notavelmente, a antiga civilização havaiana e os havaianos de hoje não se deixam afetar pela hybris ocidental. Em outras palavras, nosso caminho não é o único caminho humano possível. É concebivelmente mutável ${ }^{41}$.

A lembrança de tal contingência é imprescindível como condição essencial para um clinamen socioambiental, espécie de guinada anti-horária da dinâmica ecomental hegemônica, não no sentido de reverter a flecha do tempo, desfazendo o feito, mas de torná-la controversa, capaz de outras linhas de evolução, imprevisíveis. Bateson afirma que uma tal guinada está em curso, instada por um desejo que paradoxalmente se intensifica com o incremento da própria aceleração horária do sistema industrial:

Essa mudança em nosso pensamento já começou - entre cientistas e filósofos, e entre as pessoas jovens. Mas não são apenas professores de cabelos compridos e jovens de cabelos compridos que estão mudando suas maneiras de pensar. Há também muitos milhares de empresários e até mesmo legisladores que desejam poder mudar, mas sentem que seria inseguro ou contrário ao "bom senso" fazê-lo. As mudanças continuarão tão inevitavelmente quanto o progresso tecnológico. [...] ninguém pode prever quais novos padrões emergirão dessas mudanças drásticas. Esperamos que o período de mudança possa ser caracterizado pela sabedoria, e não pela violência ou pelo medo da violência ${ }^{42}$.

\section{A quarta lei}

No one can win against kipple, except temporarily and maybe in one spot, like in my apartment

I've sort of created a stasis between the pressure of kipple and nonkipple, for the time being. But eventually I'll die or go away, and then the kipple will again take over. It's a universal principle operating throughout the universe. The entire universe is moving toward a final state of total, absolute kippleization. Philip K. Dick, Do Androids Dream of Electric Sheep?

Em Capitalismo e colapso ambiental, Luiz Marques defende a tese segundo a qual o capitalismo é intrinsecamente insustentável. Em termos batesonianos, ele constituiria um sistema ecomental que exemplifica exponencialmente a máxima de que "a criatura que vence seu ambiente destrói-se a si mesma". Segundo Marques, trata-se de um sistema radicalmente divergente dos sistemas vivos, pois não é homeostático, capaz de "feedback negativo", ou seja, de retroagir sobre si de modo a compensar, graças a trocas com o ambiente exterior, o aumento de entropia positiva (desordem destrutiva). Seria, pois, um erro "atribuir ao mercado os atributos da homeostase":

Atingida sua escala ideal, todo organismo cessa de crescer e passa à fase em que prevalecem adaptações conservativas. Esse fenômeno não ocorre no mercado capitalista, o qual é impelido por forças centrífugas (impostas pela acumulação de capital) em direção a um crescimento ilimitado. 0 tamanho ideal do mercado capitalista é, por definição, o infinito. Contrariamente ao organismo, se o mercado capitalista não cresce, ele se desequilibra. Se a era do crescimento capitalista chegou ou está chegando ao fim, isso não se deve a

41 BATESON, Steps to an Ecology of Mind, 501.

42 BATESON, Steps to an Ecology of Mind, 501. 
uma suposta virtude homeostática do mercado, mas a algo que lhe é completamente externo e estranho: os limites físicos de resiliência da biosfera ${ }^{43}$.

Marques evoca então a "bioeconomia” de Georgescu-Roegen:

“O domínio dos fenômenos que a ecologia abrange é mais amplo que o domínio coberto pela ciência econômica", de tal modo que "a economia deverá ser absorvida pela ecologia". No capitalismo, ao contrário, o meio físico é concebido como matéria-prima, como um subsistema do sistema econômico. Há aqui uma inversão da taxis que resulta num ordenamento hierárquico do mundo incompatível com sua concepção ecológica. A faculdade de subordinar as metas econômicas ao imperativo ambiental não pertence, portanto, às coordenadas mentais do capitalismo ${ }^{44}$.

Uma enorme e terrível inversão decorrente da transformação metafísica operada pela revolução industrial: a natureza passa a ser compreendida como "subsistema do sistema econômico". No contexto de um diagnóstico crítico da situação ecológica da economia, essa ideia é problematizada com profundidade por Georgescu-Roegen em seus escritos sobre entropia e economia. Tomemos uma conferência sua de 1970, mesmo ano do comunicado de Bateson, intitulada "A lei da entropia e o problema econômico". 0 economista parte da ideia de que, como sistema físico-termodinâmico, todo sistema econômico absorve matéria-energia do ambiente para devolvê-la sob outra forma, qualitativamente distinta: "Do ponto de vista da termodinâmica, a matéria-energia absorvida pelo processo econômico o é num estado de baixa entropia e sai num estado de alta entropia"45. No caso da economia da civilização industrial, as consequências desse fato seriam devastadoras, representando "o principal problema para o destino da espécie humana" 46.

Quando se queima carvão para obter energia necessária ao funcionamento de máquinas a combustão, parte da "energia utilizável ou livre" nele contida se degrada irreversivelmente - pois "o carvão só pode ser utilizado uma única vez" - em "energia inutilizável ou presa", "caoticamente dissipada"47. Assim, "a baixa da entropia [na produção econômica] só pode ser obtida à custa de um aumento maior da entropia em outra parte [no meio ambiente]"48. Se "todo objeto que apresenta um valor econômico comporta uma estrutura altamente ordenada, isto é, de baixa entropia"49, isso significa o crescimento econômico, no sentido da produção industrial, conduz inexoravelmente ao colapso ambiental ${ }^{50}$.

Logo, se a termodinâmica surge como "ciência do fogo industrial", ela se constitui em "física do valor econômico"51. Com isso, a ciência da natureza confina seu horizonte especulativo à fábrica, desconectando-se do "ambiente material" mais amplo e das limitações que este impõe à produção humana: "Deixamos de reconhecer a natureza entrópica do processo econômico"52. Tal negligência assume proporções cósmicas, pois a predileção, entre as principais fontes de energia acessíveis ao homem, pelo "estoque de energia livre dos

\footnotetext{
43 MARQUES, Capitalismo e colapso ambiental, 476.

${ }^{44}$ MARQUES, Capitalismo e colapso ambiental, 477-478.

45 GEORGESCU-ROEGEN, O decrescimento: entropia, ecologia, economia, 57.

46 GEORGESCU-ROEGEN, O decrescimento: entropia, ecologia, economia, 68.

47 Cf. GEORGESCU-ROEGEN, O decrescimento: entropia, ecologia, economia, 58-59, 63.

48 GEORGESCU-ROEGEN, 0 decrescimento: entropia, ecologia, economia, 61.

${ }^{49}$ GEORGESCU-ROEGEN, 0 decrescimento: entropia, ecologia, economia, 62.

${ }^{50}$ Cf. GEORGESCU-ROEGEN, 0 decrescimento: entropia, ecologia, economia, 62-64.

51 GEORGESCU-ROEGEN, O decrescimento: entropia, ecologia, economia, 59.

52 GEORGESCU-ROEGEN, O decrescimento: entropia, ecologia, economia, 65.
} 
depósitos minerais nas entranhas da Terra", em detrimento da energia contida no "fluxo dos raios solares interceptados pela Terra", levará o sistema econômico a um "beco sem saída":

A esse respeito, nada é mais esclarecedor do que a história da luta entrópica do homem durante os últimos duzentos anos. Por um lado, em virtude do progresso espetacular da ciência, o homem chegou a um nível quase miraculoso de desenvolvimento econômico. Por outro lado, esse desenvolvimento obrigou o homem a levar sua retirada de recursos terrestres a um grau assombroso, como atestam as prospecções em alto-mar. Ele manteve também um crescimento demográfico que intensificou a luta pelo alimento, cuja pressão atinge, em determinadas regiões, índices críticos. A solução unanimemente preconizada consiste em incrementar a mecanização da agricultura. [...] Mas o mais importante é que resulta, da produção de baixa entropia, um deslocamento da fonte solar para a fonte terrestre. 0 boi ou o búfalo, cuja potência mecânica procede da luz solar captada pela fotossíntese clorofiliana, é substituído pelo trator, que é fabricado e acionado por meio de baixa entropia terrestre. [...] Por conseguinte, a mecanização da agricultura é uma solução que, embora inevitável no impasse atual, deve ser considerada, a longo prazo, antieconômica. Ela ocasiona, para a existência biológica do homem, uma dependência cada vez mais em relação à fonte de baixa entropia mais escassa. Apresenta também o risco de levar o homem a um beco sem saída em razão da possível extinção de algumas espécies biológicas associadas à cultura orgânica53.

Em suma, uma má orientação cosmológica - o "deslocamento da fonte solar para a fonte terrestre" - está na raiz da crise ecológica - diríamos hoje, da catástrofe socioambiental - provocada pelo desenvolvimento econômico do sistema industrial. Condição indispensável para esse desenvolvimento viabilizado pelo avanço tecnológico e exigido pelo crescimento populacional dele decorrente, a substituição do Sol pela Terra, da vida pela máquina, do arado pelo automóvel, respectivamente como fontes e meios de obtenção de energia, fez com que "o homem se tornasse, por isso mesmo, tributário de uma fonte parcimoniosíssima de subsistência, indo até a intoxicar-se do luxo da civilização industrial"54. Não há luxo sem lixo "sempre maior"55.

Trata-se aí da "quarta lei da termodinâmica", formulada originalmente por GeorgescuRoegen em um gesto transgressivo de subordinação do processo econômico à entropia cósmica: "Em todo sistema fechado, a matéria utilizável se degrada irreversivelmente em matéria não utilizável"56. Ao contrário do que reza a cosmologia baseada na termodinâmica clássica, o sistema industrial - não o universo! - é que é "o único sistema verdadeiramente fechado"57. E as consequências desse enclausuramento ecomental da física industrial não poderiam ser mais devastadoras. Como demonstra Georgescu-Roegen, "a conclusão salta aos olhos":

É certo que, quanto mais elevado for o grau de desenvolvimento econômico, mais considerável será o desgaste anual de matéria-energia e, por conseguinte, mais curta será a expectativa de vida da espécie humana. [...] Toda vez que produzimos um automóvel, destruímos irreversivelmente uma quantidade de baixa entropia que, de outra maneira, poderia ser usada para fabricar um arado ou uma enxada. Em outras palavras, toda vez que

\footnotetext{
53 GEORGESCU-ROEGEN, O decrescimento: entropia, ecologia, economia, 67-68.

${ }^{54}$ GEORGESCU-ROEGEN, 0 decrescimento: entropia, ecologia, economia, 69.

55 Cf. GEORGESCU-ROEGEN, O decrescimento: entropia, ecologia, economia, 62, 65.

56 GEORGESCU-ROEGEN, $O$ decrescimento: entropia, ecologia, economia, 169.

57 ASIMOV, Escolha a catástrofe, 21.
} 
produzimos um automóvel, isso é feito ao preço de uma baixa no número de vidas humanas futuras ${ }^{58}$.

Há nisso um notável complexo a/entrópico: a antropia industrial é desastrosamente entrópica, não só porque produz desordem ambiental mas, sobretudo, porque essa desordem, a do sistema Terra, retroage - negativamente para este último, positivamente para o sistema industrial - no sentido de promover a extinção da espécie humana. Entropia, desastre ecológico, versus antropia, desenvolvimento econômico.

A saída a esse destino nefasto seria "planificar o decrescimento econômico" para "passar lentamente e sem catástrofes para uma tecnologia menos 'quente"”59. Essa proposta data de 1981. De lá para cá, como finalmente todos sabemos, com a expansão e a aceleração sempre crescentes do sistema industrial, com o avanço da tecnologia e o crescimento populacional sempre maiores, o cenário atual só confirma o pior dos prognósticos. De sua parte, Marques conclui:

Não estamos mais apenas negando a sustentabilidade futura, mas a sobrevivência da sociedade atual. [...] Não é mais ponto da pauta de hoje debater sobre a "melhor" sociedade. 0 que hoje está em pauta é apenas como evitar o colapso ambiental que nos ameaça e que põe em risco a sobrevivência de qualquer sociedade complexa. Hoje, a utopia é essa sobrevivência. Isso posto, o paradoxo de nossos dias é que a arruinada ideia de revolução social, expulsa pela porta dos fundos no século XX, retorna hoje, ainda que profundamente diversa, pela porta da frente. Pois para deter a tendência ao colapso precisaremos instituir um contrato natural que não será politicamente factível, nem filosoficamente concebível, sem a mais radical redefinição da posição de nossa espécie na teia da vida, redefinição que equivale a uma revolução muito mais ambiciosa que todas as precedentes ${ }^{60}$.

\section{Prometeu I e II}

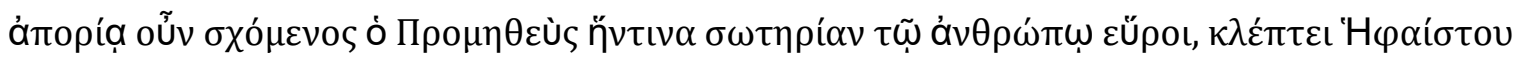

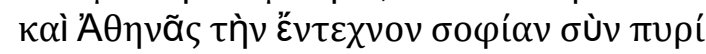
Platão, Protágoras, 321c-d

Em "A degradação entrópica e o destino prometeico da tecnologia humana", Georgescu-Roegen, a fim de "compreender a verdadeira natureza da atual crise de energia", propõe uma síntese da "evolução tecnológica" restrita a "duas inovações realmente cruciais"61 ao longo da história da relação entre técnica humana e energia material - em termos de processos ecomentais, entre antropia e entropia.

A primeira "era tecnológica", marcada pelo "domínio do fogo", é "inaugurada pelo dom de Prometeu I"62. Concretamente, trata-se do domínio técnico da "conversão qualitativa de energia" operada pelo fogo, mediante a queima de madeira, de "energia química em energia calorífica"63. Consistindo na combustão de matéria altamente utilizável, de baixíssima entropia - a saber, de matéria viva, complexamente ordenada -, esse modo de produção de energia provocou, com o holocausto das florestas, o esgotamento entrópico,

\footnotetext{
58 GEORGESCU-ROEGEN, 0 decrescimento: entropia, ecologia, economia, 68-69.

${ }^{59}$ GEORGESCU-ROEGEN, 0 decrescimento: entropia, ecologia, economia, 179.

60 MARQUES, Capitalismo e colapso ambiental, 609-610.

${ }^{61}$ GEORGESCU-ROEGEN, O decrescimento: entropia, ecologia, economia, 176.

62 GEORGESCU-ROEGEN, O decrescimento: entropia, ecologia, economia, 176.

${ }^{63}$ GEORGESCU-ROEGEN, O decrescimento: entropia, ecologia, economia, 176.
} 
progressivamente degradante, das suas fontes: "Durante a segunda metade do século XVII, a alta da crise obrigou os governos, na Grã-Bretanha e em todo o continente [europeu], a submeter o corte de madeira de florestas a severas restrições"64. Embora muitas outras florestas, mundo afora, tenham sido sacrificadas para compensar a escassez das fontes europeias, pode-se conclui que a referida crise, situada no começo da modernidade, resultou no colapso de Prometeu I.

Já a segunda era, presidida por Prometeu II, tem sido caracterizada pela exploração dos combustíveis fósseis, ou seja, de matéria morta, dificilmente utilizável, embora de baixa entropia, mas com altíssima produção de entropia positiva. Carnot, um dos arautos de Prometeu II, a quem se deve a primeira formulação da segunda lei da termodinâmica, afirmava entusiasticamente, na abertura de suas Reflexões sobre a potência motriz do fogo $e$ sobre as máquinas aptas a desenvolver essa potência:

Todo mundo sabe que o calor pode produzir movimento e que possui um vasto poder motriz de que ninguém pode duvidar, nestes dias em que o motor a vapor é conhecido em toda parte. Ao calor são devidos os grandes movimentos que se realizam sobre a Terra. Ele causa as agitações da atmosfera, a ascensão das nuvens, a queda da chuva e dos meteoros, as correntes de água que canalizam a superfície do globo e de que o homem até agora empregou apenas uma pequena porção. Até mesmo terremotos e erupções vulcânicas são o resultado do calor. Desse imenso reservatório podemos extrair a força motriz necessária para os nossos propósitos. A natureza, ao nos fornecer combustíveis de todos os lados, deu-nos o poder de produzir, em todos os tempos e os lugares, o calor e o poder propulsor que dele resulta. Desenvolver esse poder, adequá-lo aos nossos usos, é o objetivo dos motores térmicos. 0 estudo desses motores é de grande interesse, sua importância é enorme, seu uso está aumentando continuamente, e eles parecem destinados a produzir uma grande revolução no mundo civilizado ${ }^{65}$.

Para Carnot, a grande revolução realizada por meio do controle maquínico da energia térmica permitiria o desenvolvimento econômico sem precedentes da humanidade e a dominação colonial plena do planeta, nada menos que uma civilização mundial movida a doses sempre crescentes de calor. Não deixa de ser profético que a maioria dos escritos de Carnot, vítima da epidemia de cólera que se abateu sobre a Europa nas primeiras décadas do século XIX, tenham sido incinerados, junto com o cadáver do seu autor, devido à natureza contagiosa da doença - contágio, aliás, provocado pelos acelerados deslocamentos populacionais decorrentes da colonização e do imperialismo, somente possibilitados por navios e trens movidos a energia térmica.

Todavia, a exploração da fonte calorífica fóssil, impedida por obstáculos subterrâneos de terra e água, exigira uma quantidade exorbitante de energia motora suplementar, a qual somente veio a ser obtida com o dom de Prometeu II: "A máquina a vapor representa, à semelhança do fogo, uma conversão qualitativa, da energia calorífica em energia motora"66. Com isso, madeira e carvão, em quantidades declinantes, foram empregados como fontes energéticas para o funcionamento de máquinas capazes de permitir a obtenção e o consumo de combustíveis fósseis, com o objetivo principal de fazer funcionar as mesmas máquinas para obtenção e consumo de ainda mais energia:

Com uma única máquina a vapor e um pouco de carvão, é possível extrair carvão e outros minerais em quantidade suficiente para produzir outras máquinas a vapor, com as quais é possível produzir mais máquinas a vapor, e

\footnotetext{
${ }^{64}$ GEORGESCU-ROEGEN, 0 decrescimento: entropia, ecologia, economia, 176.

65 CARNOT, Reflexões sobre a potência motriz do fogo e sobre as máquinas aptas a desenvolver essa potência, 1-2.

66 GEORGESCU-ROEGEN, O decrescimento: entropia, ecologia, economia, 177.
} 
assim sucessivamente, enquanto houver combustível bastante e minerais apropriados 67.

Trata-se de um círculo entropológico vicioso, a produzir altíssima entropia a partir da baixa entropia de fontes terrenas e subterrâneas não renováveis. Um "processo em cadeia" cujo resultado entrópico é acelerada e maximamente degradante, tanto pelo esgotamento das fontes quanto pelos custos enormemente destrutivos: "Mas, agora, a extraordinária aventura mineralógica que teve início há quase duzentos anos se aproxima prematuramente de seu fim por obra inevitável do segundo legado prometeico"68. Se Prometeu III ainda permanece uma quimera, seja devido à negligência da energia solar, ou à dificuldade em obtê-la em escala suficiente, ou ainda, à exequibilidade temerária da conversão de "materiais férteis em combustíveis físseis", capazes de "superregeneração"69, a história do conflito entre antropia e entropia tem sido marcada até a presente "era" pela renovação suicida de um legado catastrófico, isto é, pelo desastre em curso de Prometeu II, alimentado pela falência continuada de Prometeu I. É do Antropoceno que estamos tratando ${ }^{70}$.

A proposta de Georgescu-Roegen consiste no decrescimento econômico como via de acesso a uma "tecnologia menos 'quente""71. Nosso autor a faz décadas antes do estabelecimento do consenso científico público em torno à elevação da temperatura média da Terra operada por fatores antropogênicos oriundos precisamente do legado prometeico. Todavia, ele é bastante pessimista, não só quanto à possibilidade de uma urgente "conversão heliocêntrica" da perspectiva antrópica, mas sobretudo quanto à capacidade de uma mudança radical na maneira de viver que o decrescimento econômico demanda da civilização industrial, a exigir, junto com o término "planejado" do capitalismo, seu "desapego ao conforto exossomático (derivado dos órgãos destacáveis)"72 para o necessário reposicionamento da própria humanidade como espécie viva na biosfera. Como se "a" humanidade estivesse "geneticamente" programada - ou melhor, noeticamente condicionada - para inflamar-se em uma conflagração tão súbita quanto "universal":

Talvez o destino do homem seja ter uma existência breve, mas febricitante, excitante e extravagante, em vez de uma existência longa, vegetativa e monótona. Genes atávicos, muito resistentes, fazem do homem um animal fundamentalmente agressivo e egoísta. Assim, mesmo que o Homo sapiens sapiens possa compreender o que tem de fazer para a sua salvação ecológica, sua natureza o impede de seguir o conselho da sabedoria. Com certeza, há uma crise de energia, mas, ao que parece, a verdadeira crise é a crise da sabedoria humana ${ }^{73}$.

Não faltam razões para contestar tal determinismo genético no comportamento cosmicamente fascista da espécie humana em sua configuração energético-industrial74. Para começar, não há nada de "vegetativo e monótono" na maneira como outras civilizações e povos humanos, incomparavelmente mais numerosos em diversidade e duradouros em existência, realizaram, e ainda realizam, ecologicamente seus mundos - a não ser, claro, que se entenda por "vegetativa" a capacidade humana de emular, com o aproveitamento da energia celeste, a conversão energética operada pela fotossíntese clorofiliana... Logo, ainda que se

\footnotetext{
67 GEORGESCU-ROEGEN, O decrescimento: entropia, ecologia, economia, 177.

68 GEORGESCU-ROEGEN, 0 decrescimento: entropia, ecologia, economia, 177.

${ }^{69}$ GEORGESCU-ROEGEN, 0 decrescimento: entropia, ecologia, economia, 178.

70 Cf. DANOWSKI \& VIVEIROS DE CASTRO, Há mundo por vir? Ensaio sobre os medos e os fins; e MARQUES, Capitalismo e colapso ambiental.

${ }^{71}$ GEORGESCU-ROEGEN, O decrescimento: entropia, ecologia, economia, 179.

72 GEORGESCU-ROEGEN, O decrescimento: entropia, ecologia, economia, 180.

73 GEORGESCU-ROEGEN, 0 decrescimento: entropia, ecologia, economia, 180.

${ }^{74}$ Cf. GEORGESCU-ROEGEN, 0 decrescimento: entropia, ecologia, economia, 180, nota 21.
} 
creia em um fundamento "natural" que impeça a humanidade ocidental de seguir o conselho de sua própria sabedoria, é certo que outras sabedorias humanas seriam capazes, porque o têm sido desde há muitíssimo tempo, de subverter aquela determinação pretensamente inviolável 75 .

Seja como for - e eis o que mais importa no diagnóstico de Georgescu-Roegen (nisso, inteiramente de acordo com o de Bateson) -, a crise de energia e a crise do espírito encontram-se tão sistemicamente imbricadas que se poderia falar, sem prejuízo do rigor científico-especulativo, de uma noética ígnea como "faculdade" de variação dinâmica do arranjo entre entropia e antropia enquanto processos ecomentais. De fato, a sabedoria técnica

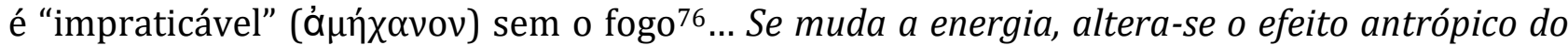
espírito; se muda o espírito, transforma-se a qualidade entrópica da energia. Além de Prometeu I e II, existem, e sempre existiram, "outros demônios"77.

De fato, que a representação demonológica de Maxwell seja "antropomórfica” não significa que ela seja necessariamente antropocêntrica. Vimos, com Prigogine \& Stengers e com Bateson, que todo sistema é essencialmente sensível ao seu ambiente externo e interno, descrevendo evoluções irreversíveis, criadoras e destruidoras, a depender, como diz Almeida, de critérios que não são "jamais naturais", e sim "políticos", mas que excedem em muito os limites da política estritamente humana. Se a representação de Maxwell pode ser antropomórfica, sua imagem - ou seja, sua disposição estrutural em um sistema ecomental não é menos monstruosa. Há demônios que conspiram ocasionalmente em favor da humanidade, outros que tramam incessantemente contra ela, e outros ainda que se comportam como agentes duplos, todos eles encarnando diferentes arranjos a/entrópicos ${ }^{78}$. A respeito da política extra-humana dos demônios termodinâmicos, Almeida afirma:

O destino de Terra-Gaia está ligado à luta entre o povo de Gaia ou Terranos e as corporações coletivas representadas por bancos e governos. Essa visão oferece a possibilidade de um ativismo antropológico que não seja condescendente; por exemplo, as alianças entre comunidades biológicohumanas contra a acumulação de capital entendida como a destruição dos recursos naturais e da diversidade das organizações humanas nãocapitalistas. Usando a linguagem dos "Demônios de Maxwell", essas estratégias representariam uma resistência contra a expropriação territorial, contra a desagregação institucional e contra a erosão ontológica. A luta contra a erosão das diferenças é a ação dos "Demônios de Maxwell" opondo-se ao impulso homogeneizador da civilização industrial. Esta luta não está ligada a nenhuma forma ou conceito particular de humanidade e pode, portanto, ser descrita como uma oposição anarquista à civilização modernista ${ }^{79}$.

\section{Fogo imaginal}

By red flower, Bagheera meant fire. Every beast lives in great fear of it. No one in the jungle will call it by its proper name. Rudyard Kipling, The Jungle Book

\footnotetext{
75 Cf. KOPENAWA \& ALBERT, A queda do céu: palavras de um xamã yanomami; KRENAK, Ideias para adiar o fim do mundo; e KRENAK, $A$ vida não é útil.

${ }^{76}$ CASSIN, O efeito sofístico: sofística, filosofia, retórica, literatura, 334.

77 Cf. ALMEIDA, Local Struggles with Entropy: Caipora and Other Demons.

78 NEGARESTANI, Cyclonopedia: Complicity with Anonymous Materials, 111 e ss.

${ }^{79}$ ALMEIDA, Local Struggles with Entropy: Caipora and Other Demons, 282-283.
} 
No Capítulo 5 de $A$ psicanálise do fogo, "A química do fogo: história de um falso problema", Bachelard parte de uma constatação generalizante que aponta para a indissociabilidade entre "física" e "psicologia" do fogo: "No caso do fogo, mais do que de qualquer outro fenômeno, as concepções animistas e as concepções substancialistas encontram-se misturadas de maneira inextricável"80. "Ultravivo"81, "o fogo se alimenta como um ser vivo", e a combustão não é senão uma espécie de metabolismo elemental: é preciso controlar a digestão do fogo, a fim de impedir que ele, seguindo sua tendência supostamente natural, devore todas as coisas. Em meio às referências cosmológicas supostamente précientíficas (poéticas, mágicas, alquímicas etc.) coligidas por Bachelard, destaca-se a seguinte:

\begin{abstract}
Assim, nada mais comum, nas cosmologias da Idade Média e da época précientífica, do que a noção de alimento para os astros. Em particular, a função das exalações terrestres é frequentemente servir de alimento aos astros. As exalações alimentam os cometas. Os cometas alimentam o Sol. [...] Robinet escreve em 1766: "Já se disse com bastante verossimilhança que os globos luminosos se nutrem das exalações que retiram dos globos opacos e que o alimento natural desses últimos é o fluxo de partes ígneas que os primeiros lhes enviam continuamente; e que as manchas do Sol, que parecem estenderse e escurecer todos os dias, não são mais que um acúmulo de vapores grosseiros que ele atrai, fazendo aumentar seu volume; que esses vapores que acreditamos ver elevarem-se em sua superfície estão na verdade precipitando-se; que, no final, o Sol absorverá uma quantidade tão grande de matéria heterogênea que não será apenas envolvido e coberto por ela, como pretendia Descartes, mas totalmente penetrado. Então ele se extinguirá, morrerá, por assim dizer, ao passar do estado de luz, que é sua vida, ao de opacidade, que constitui, para ele, uma verdadeira morte. Do mesmo modo, a sanguessuga morre ao fartar-se de sangue". Vê-se que a intuição digestiva comanda: para Robinet, o Sol Rei morrerá de indigestão. [...] Sem o mito da digestão, sem esse ritmo inteiramente estomacal do Grande Ser que é o Universo, que dorme e come harmonizando seu regime ao dia e à noite, muitas intuições pré-científicas ou poéticas seriam inexplicáveis ${ }^{82}$.
\end{abstract}

Apesar da atitude duplamente irônica com respeito ao que chama de pensamento précientífico (além da mais óbvia, parece haver também uma ironia voltada contra o dogmatismo científico), Bachelard entrevê certa indiscernibilidade entre fenômenos celestes e terrestres, ou melhor, o sistema ecomental formado por Sol e Terra - sistema do qual a biosfera constitui um espécie de mediador, virtualmente capaz de regular o conflito entre os polos celestre e terrestre. Dependendo de como os viventes reagem ao fogo, o Sol pode abrasar a Terra por conflagração, ou a Terra pode fazer o Sol definhar por inanição.

Nesse sistema, tudo é feito de fogo: o Sol é fogo inflamado, a Terra, fogo congelado, e a vida, fogo encarnado, "oculto, invisível, sem chama" (Bachelard 2008: 116). Bachelard encontra aí uma espécie de fusão entre materialismo e animismo, um "calorismo", implicando a variação anímica do fogo universalmente constitutivo:

A teoria desse fogo imanente à matéria determina um materialismo especial para o qual seria preciso criar uma palavra, pois representa uma nuance filosófica importante, intermediária entre materialismo e o animismo. Esse calorismo corresponde à materialização de uma alma ou à animação da matéria, é uma forma de passagem entre matéria e vida ${ }^{83}$.

\footnotetext{
${ }^{80}$ Cf. BACHELARD, A psicanálise do fogo, 92, 119.

81 BACHELARD, A psicanálise do fogo, 11.

82 BACHELARD, A psicanálise do fogo, 99-100.

${ }^{83}$ BACHELARD, A psicanálise do fogo, 111-112.
} 
Trata-se de uma passagem tensa, com espírito, vida e matéria situados em meio a um conflito cósmico entre Sol e Terra. De tal ponto de vista, a incandescência de uma chama revela-se como um fenômeno antigravitacional pelo qual o Sol reclama para si o que a Terra lhe havia tomado. A esse respeito, Bachelard cita Madame du Châtelet:

O Fogo é, portanto, o antagonista perpétuo da gravidade, em vez de ser-lhe submisso; assim, na Natureza, tudo se encontra em perpétuas oscilações de dilatação e contração pela ação do Fogo sobre os corpos, e a reação dos corpos que se opõem à ação do fogo pelo peso e a coesão de suas partes ${ }^{84}$.

A despeito da ironia que dedica ao conjunto dessas ideias, afirmando que elas exprimem antes efeitos subjetivos e atividades inconscientes do espírito humano que causas objetivas e propriedades essenciais da matéria inumana, Bachelard termina por embaralhar de vez os termos, propondo, juntamente com sua psicanálise do fogo, uma "física do inconsciente" 85 . Isso se torna especialmente evidente quando o filósofo identifica nas próprias "contradições" do espírito um nexo essencial, potencialmente catastrófico, com a dinâmica entrópica do fogo:

A interiorização do fogo não apenas exalta suas virtudes, como também prepara as mais formais contradições. 0 que, em nosso entender, é uma prova de que se trata, não de propriedades objetivas, mas de valores psicológicos. 0 homem é, talvez, o primeiro objeto natural em que a natureza procura contradizer-se. Aliás, é essa a razão pela qual a atividade humana está em via de mudar a face do planeta ${ }^{86}$.

Afinal de contas, os "embaraços" espirituais ${ }^{87}$ com respeito ao fogo seriam expressões de um conflito inerente à própria natureza? Se a atividade noética fosse apenas abstrata, não haveria por que recear seus efeitos antrópicos ignitivos. Direto ao ponto: se o pensamento não pudesse, a seu modo, inflamar o ambiente, não estaríamos mergulhados no "Piroceno"88. Com sua origem antrópica, a catástrofe ambiental planetária atesta que o pensamento é intrinsecamente ígneo.

Justamente nesse último sentido, Romandini comenta a epistemologia mágica de Ficino:

Resulta de particular interesse a identificação ficiniana do spiritus animalis com o fogo interior por sua natureza solar e, portanto, semelhante ao raio. [...] Esta teoria é, do ponto de vista filosófico, do maior interesse, pois se constitui, ao mesmo tempo, para além de toda fenomenologia e de todo realismo. De um ponto de vista ontológico, é preciso admitir que o mundo não é meramente uma realidade objetiva que se impõe a um sujeito perceptor pela ação direta sobre os sentidos. Por outro lado, as capacidades do aparato sensorial do perceptor são, por si só, incapazes de captar, de forma direta ou transcendental, a realidade fenomênica do mundo que, de fato, a rigor, não existe per se na filosofia ficiniana. Ao contrário, a percepção tem lugar graças a uma medialidade que se produz pela intersecção do fogo interior que emana do sujeito com o fogo exterior que emana dos objetos. Desta maneira, não se conhece um objeto, mas sim o fogo imaginal que emana deste, assim como um sujeito não percebe pelas suas próprias potências sensitivas, mas sim, rigorosamente, pela fusão de seu raio interior com o raio exterior. Exatamente nesse ponto, produz-se um meio no qual o mundo pode se

\footnotetext{
${ }^{84}$ BACHELARD, A psicanálise do fogo, 121.

85 BACHELARD, A psicanálise do fogo, 122.

${ }^{86}$ BACHELARD, A psicanálise do fogo, 112-113.

${ }^{87}$ BACHELARD, A psicanálise do fogo, 89.

88 Cf. PYNE, Fire: A Brief History.
} 
manifestar. Neste sentido, o mundo tem lugar somente na medialidade. Dito de outro modo, o mundo não se manifesta nem no objeto nem no sujeito, mas sim em um lugar extra-objetivo e extra-subjetivo que é o meio ígneo. Estamos, pois - é o mínimo que podemos dizer -, na presença de uma metafísica que contém uma visão triádica do existente, na qual "o mundo" não pertence, propriamente, nem ao objeto nem ao sujeito, mas que, antes, abre lugar em um espaço ontologicamente terceiro e independente cuja geografia ainda não foi inteiramente descrita ${ }^{89}$.

Não são poucas nem fortuitas as aproximações que se podem delinear entre a magia filosófica de Ficino e, por exemplo, a ecologia mental de Bateson, o bioeconomia de Georgescu-Roegen e talvez, malgrado ela mesma, a psicanálise ígnea de Bachelard. Em todos os casos, trata-se basicamente de compreender a imanência entre processos físicos e mentais: o conhecimento do mundo só é possível porque um "fogo imaginal" emana da natureza para encontrar o "fogo solar" do espírito - e vice-versa. Na condição de medium desse encontro, o mundo consiste em um complexo entrópico de intercâmbio de materiais imaginais e energias espirituais, aquém e além do humano, com a humanidade sendo apenas uma linha de transmissão, entre inúmeras outras, entre Sol e Terra. Aquilo que, resumindo um corolário principal da termodinâmica, Almeida diz a respeito da passagem do tempo ${ }^{90}$, poder-se-ia afirmar também a respeito do próprio mundo, a saber, que ele só pode ser experimentado em sua existência graças à dinâmica entrópica da evolução irreversível de matéria-energia da qual se compõe. A geografia do cosmos - espaço "extra-objetivo" e "extra-subjetivo" - é entropológica.

A complexidade geográfica desse mundo medial é objeto privilegiado de consideração pela magia filosófica inspirada na tradição hermética da antiguidade. Na abertura dos seus Três livros de filosofia oculta, de 1533, Cornelius Agrippa postula a existência de um "mundo triplo": "elementar, celestial e intelectual"91, favorecendo uma dupla interpretação no que se refere ao terceiro: como intermediário e/ou supraceleste. A dificuldade reside no peso conferido à hierarquia entre eles: se "todo inferior é governado por seu superior"92, faria sentido interpretar a terceira "dimensão" como divina, superior às duas primeiras. Por outro lado, ao fazer corresponder a essa triplicidade a divisão da filosofia em "natural, matemática e teológica"93, Agrippa inclui na terceira dimensão as potências demoníacas, situadas entre as dimensões terrestre e celeste, como intercessores. Ao explicar a "tripla natureza" dos quatro elementos - fogo, ar, água e terra -, distinguindo-os entre (i) os simples, imutáveis e puros, (ii) os compostos, mutáveis e impuros, mas redutíveis à simplicidade, e (iii) os "duas vezes compostos", irredutíveis, ele privilegia estes últimos sobre os demais, afirmando serem "o meio infalível, chamado de natureza do meio ou alma da natureza do meio", por constituir "a perfeição de todo efeito em todas as coisas, naturais, celestiais ou supercelestiais"94. É como se a medialidade da terceira espécie de elemento consistisse na razão da pervasividade coesa do cosmos, sua unidade complexa e dinâmica.

Entre os elementos, o fogo é o que melhor corresponde à terceira característica:

O fogo em todas as coisas, e por meio de todas as coisas, vem e vai sempre brilhante, é brilhante em todas as coisas e ao mesmo tempo oculto e desconhecido; quando está sozinho (sem outra matéria se aproximando, sobre a qual ele deveria manifestar sua devida ação), ele é ilimitado e invisível, autossuficiente para toda ação que lhe é própria, móvel, entregando-

\footnotetext{
${ }^{89}$ ROMANDINI, Do espectro da metafísica à metafísica do espectro, 16.

${ }^{90}$ ALMEIDA, Simetria e entropia: sobre a noção de estrutura em Lévi-Strauss, 184.

${ }^{91}$ AGRIPPA, Três livros de filosofia oculta, 78.

${ }^{92}$ AGRIPPA, Três livros de filosofia oculta, 78.

${ }^{93}$ AGRIPPA, Três livros de filosofia oculta, 80.

${ }^{94}$ AGRIPPA, Três livros de filosofia oculta, 85.
} 
se de certa maneira a todas as coisas que a ele se achegam, renovando, respeitando a natureza, iluminando, não compreendido por luzes que são veladas, claro, saltitante em retrocesso, curvando-se para a frente, rápido de movimento, algo sempre em ascensão, compreendendo os outros, e não sendo compreendido, não precisando de outro, secretamente crescendo sozinho e manifestando sua grandeza às coisas que o recebem. Ativo, poderoso, de presença invisível em todas as coisas, ele não aceita afrontas nem oposição e, como por vingança, reduz tudo à obediência a si, incompreensível, impalpável, não diminuído, muito rico em todas as formas de si. 0 fogo é a parte ilimitada e malvada da natureza das coisas, podendo destruir ou produzir a maioria delas. 0 fogo em si é um e penetra todas as coisas. Também se espalha pelo firmamento e brilha: mas no lugar infernal, estreito, escuro e atormentador, participando assim dos dois extremos. Portanto, o fogo em si é um, mas naquilo que o recebe é múltiplo e, em diferentes sujeitos, distribuído de maneira diferente. Aquele fogo que usamos é, portanto, oriundo de outras coisas. Ele está nas pedras e é gerado pelo golpe do aço; está na terra e, após escavação, gera fumaça; está na água, e aquece as termas e os poços; está no fundo do mar e, espalhado pelos ventos, deixa-o quente; está no ar e o faz queimar (como vemos, às vezes). E todos os animais, todos os seres vivos e também todos os vegetais são preservados pelo calor: e tudo o que vive, vive graças ao fogo inerente. As propriedades do fogo que está acima são o calor, que torna as coisas férteis, e a luz, que dá vida às coisas. As propriedades do fogo infernal são um calor de estorricar, que consome todas as coisas, e a escuridão, que torna todas as coisas estéreis. 0 fogo celestial, brilhante, afasta espíritos das trevas; também esse nosso fogo feito com madeira tem o mesmo efeito. [...] Não foi à toa que os primeiros e mais sábios instituidores das religiões e cerimônias determinaram que as orações, cantorias e toda espécie de adoração divina não fossem realizadas sem velas ou tochas acesas ${ }^{95}$.

É notável a ambivalência do fogo elemental: brilhante e oculto, autossuficiente e difuso, criador e destruidor, uno e múltiplo, celestial e infernal, fértil e estéril, cálido e abrasador, luminoso e trevoso, sagrado e profano. 0 fogo não só varia, como os outros elementos, mas antes parecer coincidir com o fundamento de sua variância por composição e decomposição, pois está presente, como fator de transformação, em todas as configurações elementais. Graças ao fogo, tudo é vivo, e tudo queima, inclusive os espíritos. Mediadores interdimensionais, os demônios são essencialmente ígneos - como o próprio cosmos, tomado em sua medialidade multidimensional. Não é por acaso que a vida dos animais, o seu "espírito vital", esteja prioritariamente vinculada ao fogo: "[Os animais] têm em sua natureza a ferocíssima força. E também brotam de uma fonte celestial. E o fogo lhes é tão natural que, se ele se extingue, logo morrem"96. Em específico, existem os "animais do fogo": "Vivem no fogo, como as salamandras e os grilos, além dos que são de um calor incandescente, como os pombos, avestruzes, leões e aqueles que os homens sábios chamam de animais que respiram fogo"97. Com isso, a magia filosófica de Agrippa professa uma espécie de prototermodinâmica, ou melhor, uma termodinâmica noética, na qual o fogo constitui o medium da agência recíproca entre matéria e espírito.

Enfim, convém lembrar aqui o célebre poema de Blake, The Tyger (1794), que Almeida comenta nas linhas finais de "Simetria e entropia": "Onde esperamos simetria, encontramos desordem. Terminamos assim com Blake. A contradição entre a simetria e o fogo que queima nas floresta da noite não pode ser abolida"98. Tal "contradição" parece ser a mesma que

\footnotetext{
${ }^{95}$ AGRIPPA, Três livros de filosofia oculta, 88-89.

${ }^{96}$ AGRIPPA, Três livros de filosofia oculta, 99.

97 AGRIPPA, Três livros de filosofia oculta, 100.

98 ALMEIDA, Simetria e entropia: sobre a noção de estrutura em Lévi-Strauss, 188.
} 
Prigogine \& Stengers discernem no coração da entropia, e com a qual nos deparamos em diversas configurações: sua potência ao mesmo tempo criadora e destruidora, sempre longe do equilíbrio. Se não é evidente, na magia filosófica de Agrippa, a orientação noética para um desequilíbrio dinâmico, ela é invocada no poema mágico de Blake, onde, ao contrário do que sucede no Livro da selva, a "flor vermelha" surge como atributo extra-humano, antiprometeico:

Tygre! Tygre! Brilho, brasa
que a furna noturna abrasa,
que olho ou mão armaria
tua feroz symmetrya?99

Feitiço aquilino

Fire is returning to mind. Stephen J. Pyne, Fire: A Brief History

Face à "feroz symmetrya" desse Anti-Prometeu, nosso regime conceitual experimenta uma necessidade premente de transformação. No que concerne à problemática ecomental, ao mesmo tempo geo-, bio- e noológica, o que está em questão são os efeitos, a efetividade e a eficácia socioambientais, em escala micro- e macroscósmica, do pensamento filosófico. Não é possível tratar da catástrofe ambiental sem nos questionarmos a respeito de como a filosofia, assim como toda produção noética, participa desse acontecimento: se conspira para sua promoção ou se luta para subvertê-la. Para tanto, não basta a prática conceitual ortodoxa, segundo a qual "os conceitos determinam algo a priori sobre os objetos sem que sejam afetados por eles"100. Pois o desafio consiste em tratar de "objetos" - como o ambiente físico, biológico, cósmico - que detêm o poder de fazer colapsar a própria estrutura do pensamento, dependendo de como eles respondem aos efeitos entrópicos desta última.

0 privilégio conferido às imagens advém, portanto, da necessidade de permitir que esses "hiper-objetos"101 façam intrusão, virtual ou efetivamente, em nosso pensamento, na medida mesma em que ele pretende conhecê-los. Diferente do conceito como informação programada, redundante porque autorreferente, a imagem parece definir-se pela capacidade de transmitir informações sempre "novas", vindas de outras partes, além das "formas-depensamento [thought-forms] da cultura"102. Se, por exemplo, como vimos com Bateson, um diagrama conceitual pode ser a imagem de um sistema mental fechado, ele também pode ser a imagem de um sistema aberto, no qual a mente se move, consciente ou inconscientemente, em um ambiente cósmico mais amplo. Nesse segundo sentido, funcionando à maneira de uma linha de transmissão ecomental, o conceito-imagem consiste no sigilo de uma potência demoníaca, seu "feitiço".

Seja como for, quando se trata da relação entre pensamento e ambiente, antropia e entropia, espírito e fogo, as fronteiras que pretensamente separariam a filosofia da magia, as Luzes das trevas, vacilam inevitavelmente. E hoje, mais que nunca. Em uma recente conferência sobre a destruição do clima feita no Brasil, a filósofa neopagã Starhawk retoma uma célebre definição de magia, como arte de transformar o pensamento pelo desejo ("a consciência pela vontade"), para considerar a catástrofe ambiental em sua dimensão antropogênica. Visto que o desejo - segundo Starhawk, "a linguagem das coisas"103 - se

\footnotetext{
${ }^{99}$ CAMPOS, Viva Vaia: Poesia, 1949-1979, 221.

100 KANT, Dissertação de 1770/Carta a Marcus Herz, 133.

101 MORTON, Hyperobjects: Philosophy and Ecology After the End of the World.

102 STARHAWK, Dreaming the Dark: Magic, Sex \& Politics, 26.

103 STARHAWK, Dreaming the Dark: Magic, Sex \& Politics, 26.
} 
manifesta por imagens, trata-se de uma arte da imagem como força-e-forma medial, capaz de operar uma conexão ecomental, noético-ígnea, entre consciência e energia:

Sempre gostei do modo como Dion Fortune, uma ocultista do início do século $\mathrm{XX}$, define magia: segundo ela, a magia seria "a arte de modificar a consciência de acordo com a vontade". Essa definição inclui a arte e as ideias de visão e imaginação. Inclui também a ideia de mudança: implica que o mundo é dinâmico e fluido, e não estático. E ela fala de "vontade": uma intenção humana focada que tem um impacto no mundo em torno de nós. Penso que essa também é uma boa definição para a ação política. Buscar mudanças políticas profundas não abrange apenas mudar quem detém o poder, embora isso seja bastante importante. Implica também mudar o modo como concebemos o nosso poder e a consciência que permitiu que tantos danos ocorressem e tivessem continuidade. [...] Para nos opormos verdadeiramente à mudança climática, precisamos não apenas de estatísticas relativas ao carbono e ao metano. Precisamos compreender que há valores que estão além do lucro e da extração. Quando abraçamos esses valores, também recebemos de volta o imenso valor da nossa conexão intuitiva com a natureza, das formas por meio das quais a natureza se comunica e fala conosco. [...] Esse é um ensinamento mágico que dou a vocês. 0 mundo é um espaço fluido e dinâmico de energia. A energia pode ser direcionada por meio da vontade e da consciência humanas. E elas direcionam energia por meio de imagens que nos tocam, imagens sensoriais, emocionais, mais do que apenas intelectuais, de acordo com aquilo que desejamos. [...] Precisamos de uma imagem daquilo que desejamos. [...] 0 tempo está acabando. Vocês terão que descobrir isso por conta própria ${ }^{104}$.

Trata-se aí uma dupla transformação: a modificação de "formas-de-pensamento" pelo desejo, e a alteração do ambiente pela imaginação, seja destrutiva ou criadora. Essa transformação é, por natureza, demoníaca, pois conjuga desejo, pensamento e energia mediante imagens ao mesmo tempo sensíveis e sencientes. Além disso, se a "intenção humana [...] tem um impacto no mundo em torno de nós" - se, por exemplo, a política afeta o clima -, é em virtude de sua imagética libidinal. Não é por acaso que atualmente um profundo "desejo de morte e de extermínio, a um só tempo, do sentido e de qualquer forma de alteridade, que é a mola propulsora de todo fascismo"105, tem sido acompanhado pelo recrudescimento inédito da destruição socioambiental em escala planetária. Fogo e sangue.

Todavia, se o desejo transforma o ambiente, o que transforma o desejo? Será possível a transformação em sentido contrário, do desejo pelo ambiente? Isso implicaria reconhecer a magia como sendo, quanto às suas fontes e poderes, originariamente extra-humana. Parece ser o caso na cosmologia tolteca do feiticeiro yaqui Don Juan Matus, tal como exposta pelo antropólogo-feiticeiro Carlos Castaneda. Em 0 poder do silêncio, ele a resume em uma série de nove proposições. A oitava delas reza: "Intento [intent] é a força pervasiva que causa a nossa percepção. Nós não nos tornamos cientes [aware] porque percebemos; ao contrário, nossa percepção é resultado da pressão e da intrusão do intento"106.

Para um entendimento adequado dessa proposição cosmo-epistemológica, é imprescindível levar em conta dois pontos: (i) o intento é uma força cósmica exercida por uma "aglomeração infinita de campos de energia"107, em meio à qual e pela qual se constituem os diferentes seres, orgânicos e inorgânicos; (ii) o "nós" inclusivo empregado por Castaneda designa a totalidade desses seres, "além da nossa condição humana" em sentido exclusivo108.

104 STARHAWK, Magia, visão e ação, 55, 61, 65.

105 DANOWSKI, Negacionismos, 6-7.

106 CASTANEDA, The Power of Silence, XVI.

107 CASTANEDA, The Power of Silence, XV.

108 CASTANEDA, The Fire From Within, 81-82. 
Todos os seres, humanos e extra-humanos, são dotados de awareness ("atenção", "interesse", "noção", "ciência") como fundamento de sua própria existência; essa awareness, por sua vez, é ativada pelo intento enquanto potência intrusiva de formação e transformação dos seres; e é o intento que faz com que todos eles percebam o seu ambiente e dele tomem parte ativa, interessada, cientemente. Na constituição da "consciência" anímica dos seres, encontramos nada menos que um estado de indiscernibilidade entre desejo e energia. Logo, se o pensamento encerra um potencial ígneo, é porque o elemento ígneo já comporta e mesmo produz intencionalidade. $O$ cosmos é em si mesmo mágico.

Sem dúvida, a essa cosmologia corresponde uma outra "entropologia"109. "Entropologia reversa", por assim dizer, que radicaliza a subversão da flecha do tempo pela termodinâmica do não-equilíbrio por meio de uma inversão completa das relações entre vida e matéria. Em vez de reagir em vão à tendência ao colapso energético dos sistemas materiais, a vida - uma vida demoníaca - os envolve e constitui de saída, como se a entropia, no sentido da termodinâmica clássica, fosse sempre local, e nunca global (logo, também contra a lei da "bagulhificação", kippleization, formulada por Isidore). Mais uma vez, o próprio universo seria o único sistema propriamente aberto, com os seres, inorgânicos e orgânicos, que o habitam tendendo por si sós fatalmente à "desaglomeração" colapsante, não fosse o intento cósmico cuja pressão intrusiva ativa suas respectivas modalidades de consciência ao mesmo tempo neguentrópica e negantrópica:

A consciência [awareness] começa com a pressão permanente que as emanações livres exercem sobre aquelas presas dentro do casulo. Essa pressão produz o primeiro ato de consciência; ela interrompe o movimento das emanações presas, que estão lutando para quebrar o casulo, lutando para morrer. "Para um vidente, a verdade é que todos os seres vivos estão lutando para morrer. 0 que detém a morte é a consciência." Don Juan disse que os novos videntes eram profundamente perturbados pelo fato de que a consciência previne a morte e, ao mesmo tempo, a induz por ser alimento para a Águia. Uma vez que eles não podiam explicá-lo, pois não há modo racional de compreender a existência, os videntes perceberam que o seu conhecimento é composto por proposições contraditórias ${ }^{110}$.

A contradição cosmológica referida por Castaneda (a ensejar, à primeira vista, a conclusão errônea de que, a despeito da intrusão e da pressão do intento, o colapso energético seria inevitável) pode talvez ser reformulada em termos de um paradoxo entropológico literalmente mais afim à "explicação dos feiticeiros"111: a Águia - fonte sigilosa de emanação de forças cósmicas - posterga incessantemente a morte dos seres terrestres, animando-os, porém, apenas para lhe servirem de alimento. Ela transmuta, de um lado, morte ígnea em vida noética e, de outro, vida ígnea em morte noética. Tal transmutação é antes metabólica que combustiva: a devoração anímica substitui o colapso energético, na condição de télos cosmológico. Avesso ao equilíbrio inerte, porém jamais à morte dinâmica, o feitiço aquilino perfaz o ambiente cósmico como trama inextricável de emanações livres e encasuladas (à semelhança das linhas de transmissão de um sistema ecomental, segundo o animismo cibernético de Bateson).

Tal entropologia animista talvez não passasse de irresponsável extravagância, caso o fogo não estivesse "retornando à mente", isto é, voltando a fazer e desfazer sentido, após um período historicamente longo de negligência intencional favorecido por sua "transmutação intelectual de causa universal em efeito químico"112. "Graças às mudanças globais forjadas

\footnotetext{
109 LÉVI-STRAUSS, Tristes trópicos, 291.

110 CASTANEDA, The Fire From Within, 72.

111 Cf. CASTANEDA, Tales of Power.

112 PYNE, Fire: A Brief History, 138.
} 
pela combustão industrial"113, em particular, por força da devastação, cada vez mais veloz $e$ massiva, de biomas inteiros causada por um regime econômico universalmente predatório, "as semióticas materiais do fogo estão [de novo] em questão"114. Entre outras manifestações ignitivas do espírito, magia filosófica, termodinâmica clássica, termodinâmica do nãoequilíbro e feitiçaria aquilina não se deixam, portanto, reduzir a diferentes concepções, diversamente antagônicas, acerca da natureza do fogo; antes, elas exprimem regimes noéticoígneos ontológica e politicamente divergentes. Como podemos testemunhar, Bagheera e Tygre ardem hoje em meio ao cruzamento desses fogos.

De maneira similar, Pyne contrapõe à "narrativa prometeica" - poderíamos dizer, à epistemologia ambientalmente destrutiva e à termodinâmica mortífera do Capital - uma "narrativa primeva": enquanto aquela representa o fogo como recurso e arma "roubados" ao cosmos, esta última o imagina como "companheiro de jornada", proveniente de uma originária "interação entre mente e ambiente"115. E daí conclui, de maneira tão drástica quanto verossímil:

A Terra tem demasiado fogo prometeico. Tem pouco fogo primevo. 0 futuro próximo provavelmente verá a distância entre ambos se ampliar. 0 futuro longínquo, se houver, verá o fogo prometeico ser acorrentado e o primevo solto. Entre essas épocas poderemos esperar uma narrativa emaranhada, cheia de paradoxos, com respeito a que fogos são bons e quais são maus. Talvez necessitemos de fogo prometeico para fazer a transição para uma tecnologia neutra em carbono e até mesmo para protelar a próxima era do gelo. Contudo, caso seja negligenciado em sua arrogância e hybris, esse fogo poderá nos poupar do gelo tão-somente para nos lançar às chamas da perdição, enquanto o Antropoceno se transforma em um descontrolado Piroceno ${ }^{116}$.

De fato, tudo indica que a Terra tem suportado um último, cataclísmico e imprevisível confronto demoníaco entre Prometeu e a Águia em torno ao sentido material do Fogo.

\section{Referências}

AGRIPPA, C. Três livros de filosofia oculta. Compilação e notas de Donald Tyson. Tradução de Marcos Malvezzi. São Paulo: Madras, 2000.

ALMEIDA, M. 1999. Simetria e entropia: sobre a noção de estrutura em Lévi-Strauss. Revista de Antropologia, v. 42, n. 1-2, p. 163-197, jan. 1999. Disponível em: http:// www.revistas.usp.br/ra/article/view/133463. Acesso em: 20 set. 2020.

ALMEIDA, M. Local Struggles with Entropy: Caipora and Other Demons. In: M. Brightman, M. \& Lewis, J. (Eds.). The Anthropology of Sustainability: Beyond Development and Progress. London: Palgrave MacMillan, 2017.

ANDRADE, O. de. A utopia antropofágica. São Paulo: Globo, 1990.

ASIMOV, I. Escolha a catástrofe. Tradução de Amarilis Eugênia Miazzi Pereira Lima. São Paulo: Círculo do Livro, 1982.

BACHELARD, G. A psicanálise do fogo. Tradução de Paulo Neves. São Paulo: Martins Fontes, 1994.

\footnotetext{
113 PYNE, Fire: A Brief History, 138.

114 HARAWAY, Staying with the Trouble: Making Kin in the Chthulucene, 44.

115 PYNE, Fire: A Brief History, 200.

116 PYNE, Fire: A Brief History, 200.
} 
BATESON, G. Steps to an Ecology of Mind. Northvale, London: Jason Aronson Inc., 1987. CAMPOS, A. de. Viva Vaia: Poesia, 1949-1979. São Paulo: Brasiliense, 1986.

CARNOT, S. Réflexions sur la puissance motrice du feu et sur les machines propres a développer cette puissance. Paris: Bachelier, 1824.

CASSIN, B. O efeito sofístico: sofística, filosofia, retórica, literatura. Tradução de Ana Lúcia de Oliveira, Maria Cristina Franco Ferraz e Paulo Pinheiro. São Paulo: Editora 34, 2005.

CASTANEDA, C. Tales of Power. New York: Washington Square Press, 1974.

CASTANEDA, C. The Fire From Within. New York: Washington Square Press, 1984.

CASTANEDA, C. The Power of Silence. New York: Washington Square Press, 1987.

CHAKRABARTY, D. 0 clima da história: quatro teses. Tradução de Idelber Avelar (coord.).
Sopro,
V. 91 ,
p. $\quad 2-22$
jul.
2013.
Disponível
em:

http://www.culturaebarbarie.org/sopro/n91s.pdf. Acesso em: 20 set. 2020.

CHAUÍ-BERLINCK, J. \& MARTINS, R. As duas primeiras leis: uma introdução à termodinâmica. São Paulo: Editora Unesp, 2013.

DANOWSKI, D. Negacionismos. Coleção Pandemia. São Paulo: n-1 edições, 2018. Disponível em: https://issuu.com/n-1publications/docs/cordel negacionismos. Acesso em: 20 set. 2020 .

DANOWSKI, D. \& VIVEIROS DE CASTRO, E. Há mundo por vir? Ensaio sobre os medos e os fins. Florianópolis [Desterro]: Cultura e Barbárie, 2014.

DICK, P. K. Four Novels of the 1960s. New York: Library of America, 2007.

GEORGESCU-ROEGEN, N. O decrescimento: entropia, ecologia, economia. Organização de Jacques Grinevald e Ivo Rens. Tradução de Maria José Perillo Isaac. São Paulo: Senac, 2012.

HARAWAY, D. Staying with the Trouble: Making Kin in the Chthulucene. Durham and London: Duke University Press, 2016.

KANT, I. Dissertação de 1770/Carta a Marcus Herz. Tradução de António Marques. Lisboa: Imprensa Nacional-Casa da Moeda, 2004.

KIPLING, R. The Jungle Books. Edited by W. W. Robson. Oxford and New York: Oxford University Press, 1998.

KOPENAWA, D. \& ALBERT, B. A queda do céu: palavras de um xamã yanomami. Tradução de Beatriz Perrone-Moisés. São Paulo: Companhia das Letras, 2015.

KRENAK, A. Ideias para adiar o fim do mundo. São Paulo: Companhia das Letras, 2019.

KRENAK, A. A vida não é útil. São Paulo: Companhia das Letras, 2020.

LEBRUN, G. Kant e o fim da metafísica. Tradução de Carlos Alberto Ribeiro de Moura. São Paulo: Martins Fontes, 2002.

LÉVI-STRAUSS, C. Tristes trópicos. Tradução de Rosa Freire d'Aguiar. São Paulo: Companhia das Letras, 1996.

LÉVI-STRAUSS, C. A antropologia diante dos problemas do mundo moderno. Tradução de Rosa Freire d'Aguiar. São Paulo: Companhia das Letras, 2012.

MARQUES, L. Capitalismo e colapso ambiental. Campinas: Editora da Unicamp, 2016.

MARTIN, G. R. R. A Song of Ice and Fire: Books 1-5. London: Harper Collins, 2019. 
MORTON, T. Hyperobjects: Philosophy and Ecology After the End of the World. Minneapolis and London: University of Minnesota Press, 2013.

NEGARESTANI, R. Cyclonopedia: Complicity with Anonymous Materials. Melbourne: re.press, 2008.

OLIVEIRA, P. M. C. \& DECHOUM, K. Facilitando a compreensão da segunda lei da termodinâmica. Revista Brasileira de Ensino de Física, v. 25, n. 4, p. 359-363, dez. 2003. Disponível em: https://www.scielo.br/pdf/rbef/v25n4/a04v25n4.pdf. Acesso em: 20 set. 2020.

PYNE, S. J. Fire: A Brief History. Seattle and London: University of Washington Press, 2019.

PLATON. Protagoras. Texte établi et traduit par Maurice Croiset. Paris: Les Belles Lettres, 1997.

PRIGOGINE, I. \& STENGERS, I. A nova aliança: metamorfoses da ciência. Tradução de Miguel Faria e Maria Joaquina Machado Trincheira. Brasília: Editora UnB, 1984.

PRIGOGINE, I. \& STENGERS, I. Entre o tempo e a eternidade. Tradução de Roberto Leal Ferreira. São Paulo: Companhia das Letras, 1992.

PRINCE OF DARKNESS. Directed by de John Carpenter. EUA: Universal Pictures, 102 min., 1987.

ROMANDINI, F. L. Do espectro da metafísica à metafísica do espectro. Species, v. 1, p. 720, 2015. Disponível em: https://speciesnae.files.wordpress.com/2015/11/species1.pdf. Acesso em: 20 set. 2020.

SCHRÖDINGER, E. O que é vida? O aspecto da célula viva. Seguido de Mente e Matéria e Fragmentos Autobiográficos. Tradução de Jesus de Paula Assis e Vera Yukie Kuwajima de Paula Assis. São Paulo: Editora UNESP, 1997.

SERRES, M. Hermes: Literature, Science, Philosophy. Edited by Josué V. Harari and David F. Bell. Baltimore and London: The Johns Hopkins University Press, 2005.

STARHAWK. Dreaming the Dark: Magic, Sex \& Politics. Boston: Beacon Press, 1982.

STARHAWK. Magia, visão e ação. Revista do Instituto de Estudos Brasileiros, v. 69, p. 5265, abr. 2018. Disponível em: http://www.revistas.usp.br/rieb/article/view/145633/139580. Acesso em: 20 set. 2020.

VALENTIM, M. A. Extramundanidade e sobrenatureza: ensaios de ontologia infundamental. Desterro [Florianópolis]: Cultura e Barbárie, 2018.

VALENTIM, M. A. Cosmologia e política no Antropoceno. Ethic@, v. 19, n. 2, p. 300-317, 2020. Disponível em: https://periodicos.ufsc.br/index.php/ethic/article/view/16772954.2020v19n2p300/44261. Acesso em: 24 set. 2020.

VEIGA, J. O Antropoceno e a ciência do sistema Terra. São Paulo: Editora 34, 2019.

ZOLNERKEVIC, I. Quantum Trickster. Pesquisa Fapesp International Issue, p. 48-49, jan. 2018. Disponível em: https://revistapesquisa.fapesp.br/en/quantum-trickster/. Acesso em: 20 set. 2020 . 